\title{
Spectral, Molecular Modeling, and Biological Activity Studies on New Schiff's Base of Acenaphthaquinone Transition Metal Complexes
}

\author{
Khlood S. Abou Melha $\left(\mathbb{D},{ }^{1}\right.$ Gamil A. Al-Hazmi $\left(\mathbb{D},{ }^{1,2}\right.$ Ismail Althagafi $\left(\mathbb{D},{ }^{3}\right.$ Arwa Alharbi $(\mathbb{D}),{ }^{3}$ \\ Ali A. Keshk $\left(\mathbb{1},{ }^{4}\right.$ Fathy Shaaban $\left(\mathbb{C}^{5,6}\right.$ and Nashwa El-Metwaly $\mathbb{1}^{3,7}$ \\ ${ }^{1}$ Department of Chemistry, King Khalid University, P.O. Box 9004, Abha, Saudi Arabia \\ ${ }^{2}$ Department of Chemistry, Taiz University, P.O. Box 82, Taiz, Yemen \\ ${ }^{3}$ Department of Chemistry, Umm-Al-Qura University, Makkah, Saudi Arabia \\ ${ }^{4}$ Department of Chemistry, College of Science, University of Tabuk, Tabuk, Saudi Arabia \\ ${ }^{5}$ Department of Environment and Health Research, Custodian of Two Holy Mosques Institute for Hajj and Umrah Research, \\ Umm-Al-Qura University, Makkah, Saudi Arabia \\ ${ }^{6}$ Department of Geomagnetic and Geoelectric, National Research Institute of Astronomy and Geophysics, Kafr Al Masallat, Egypt \\ ${ }^{7}$ Department of Chemistry, Mansoura University, Mansoura, Egypt
}

Correspondence should be addressed to Nashwa El-Metwaly; n_elmetwaly00@yahoo.com

Received 25 November 2020; Revised 7 January 2021; Accepted 6 March 2021; Published 22 March 2021

Academic Editor: Ian S. Butler

Copyright ( $(2021$ Khlood S. Abou Melha et al. This is an open access article distributed under the Creative Commons Attribution License, which permits unrestricted use, distribution, and reproduction in any medium, provided the original work is properly cited.

\begin{abstract}
The newly synthesized Schiff's base derivative, N-allyl-2-(2-oxoacenaphthylen-1(2H)-ylidene)hydrazine-1-carbothioamide, has been characterized by different spectral techniques. Its reaction with $\mathrm{Co}(\mathrm{II}), \mathrm{Ni}(\mathrm{II})$, and $\mathrm{Zn}$ (II) acetate led to the formation of $1: 1$ (M:L) complexes. The IR and NMR spectral data revealed keto-thione form for the free ligand. On chelation with Co(II) and $\mathrm{Ni}(\mathrm{II})$, it behaved as mononegative and neutral tridentate via $\mathrm{O}, \mathrm{N}^{1}$, and $\mathrm{S}$ donors, respectively, while it showed neutral bidentate mode via $\mathrm{O}$ and $\mathrm{N}^{1}$ atoms with $\mathrm{Zn}(\mathrm{II})$. The electronic spectra indicated that all the isolated complexes have an octahedral structure. The thermal gravimetric analyses confirmed the suggested formula and the presence of coordinated water molecules. The XRD pattern of the metal complexes showed that both $\mathrm{Co}(\mathrm{II})$ and $\mathrm{Ni}$ (II) have amorphous nature, while $\mathrm{Zn}$ (II) complex has monoclinic crystallinity with an average size of $9.10 \mathrm{~nm}$. DFT modeling of the ligand and complexes supported the proposed structures. The calculated HOMO-LUMO energy gap, $\Delta \mathrm{E}_{\mathrm{H}-\mathrm{L}}$, of the ligand complexes was $1.96-2.49 \mathrm{eV}$ range where $\mathrm{HAAT}<\mathrm{Zn}$ (II) $<\mathrm{Ni}$ (II) $<\mathrm{Co}(\mathrm{II})$. The antioxidant activity investigation showed that the ligand and $\mathrm{Zn}$ (II) complex have high activity than other complexes, 88.5 and $88.6 \%$, respectively. Accordingly, the antitumor activity of isolated compounds was examined against the hepatocellular carcinoma cell line (HepG2), where both HAAT and $\mathrm{Zn}$ (II) complex exhibited very strong activity, $\mathrm{IC}_{50} 6.45 \pm 0.25$ and $6.39 \pm 0.18 \mu \mathrm{M}$, respectively.
\end{abstract}

\section{Introduction}

Schiff bases are a class of compounds that contain azomethine bond, $-\mathrm{C}=\mathrm{N}-$, which results from the condensation of active carbonyl compounds with a primary amine. The Schiff bases are very versatile where the most common Schiff bases have NO donor atoms, but in many cases, the oxygen atom may be replaced by sulfur atoms or added to the donor atoms, NS or NSO, respectively [1]. They are widely applied in several fields such as drugs [2], agriculture [3], luminescent materials $[4,5]$, and metal anticorrosion [6]. Moreover, in inorganic chemistry, Schiff bases are an interesting ligand due to their tendency to form stable complexes with most transition metal ions. The importance of Schiff base complexes has increased as they may serve as models for biologically important species $[7,8]$. 
Thiosemicarbazones, as a subclass of the Schiff bases, are formed by the reaction of ketone or aldehyde and thiosemicarbazide. Thiosemicarbazones and their complexes have noteworthy significance in biological and chemical studies [9-13]. Their multidonor atoms enable chelation with metal ions to form neutral or charged stable and colored complexes. The remarkable biological activities and varied structural properties of thiosemicarbazone metal complexes promoted their application in the development of therapeutic agents $[1,14,15]$. Lately, two compounds exhibited antitumor activity against several human cell lines [16-18]. The thiosemicarbazone biological properties altered by metal ion coordination, e.g., the lipophilicity that controls the penetration rate into the cell, are changed and so reduce the side effects. Furthermore, the complexes may show new bioactivity which is not displayed by the free ligand $[19,20]$.

Literature survey showed that acenaphthaquinone and its derivatives were widely used as starting and intermediate materials for the production of different compounds that have pharmaceutical importance [21, 22], pesticides, dyes, drugs, and versatile fluorescent chemosensor [23-26]. However, a few reports on acenaphthaquinone thiosemicarbazone derivatives were observed. The cell proliferation inhibition activity on Friend erythroleukemia cells (FLCs) of acenaphthaquinone mono-thiosemicarbazone derivative and its $\mathrm{Cu}(\mathrm{II}), \mathrm{Ni}(\mathrm{II}), \mathrm{Fe}(\mathrm{III})$, and $\mathrm{Zn}$ (II) metal complexes was reported firstly where the ligand showed stronger inhibition than metal complexes but the $\mathrm{Zn}$ (II) complex was higher than other metal complexes. The X-ray single crystal of free ligand showed dimer-like structure in which intramolecular and intermolecular hydrogen bonds were formed. The Ni(II) complex crystal structure indicated that it has distorted octahedral geometry and the ligand behaved as in mononegative tridentate fashion via ONS donors [24]. Moreover, the bimetallic $\mathrm{Hg}(\mathrm{II})$ and $\mathrm{Cd}(\mathrm{II})$ complexes derived from the 4-phenyl acenaphthaquinone4-phenyl thiosemicarbazone (APTH) spectral data indicated that the ligand coordinated to the metal ion in neutral tetradentate manner via nitrogen atoms of azomethine and $\mathrm{N}^{2} \mathrm{H}$ groups in addition to both oxygen and sulfur atoms. The APTH was employed as a chelating agent in cloud point extraction procedure of trace amounts of $\mathrm{Hg}(\mathrm{II})$ and $\mathrm{Cd}(\mathrm{II})$ ions from aqueous medium [27]. Furthermore, the acenaphthaquinone-3-(4-benzylpiperidyl)thiosemicarbazone metal complexes with $\mathrm{Co}(\mathrm{II}), \mathrm{Ni}(\mathrm{II}), \mathrm{Cu}(\mathrm{II})$, and $\mathrm{Zn}$ (II) ions were isolated, and their antibacterial activity against Gram negative and positive bacteria was studied where the complexes exhibited better activity than the ligand. The improved activity was explained by means of a drop in the polarity, which favors permeation of the complexes through the lipid layer of the bacterial cell membrane [28]. The acenaphthaquinone bis(thiosemicarbazone) precipitated onto multiwall carbon nanotubes (MWCNTs) and its $\mathrm{Zn}$ (II) and $\mathrm{Hg}$ (II) complexes were characterized by IR, TGA, XRD, SEM, and TEM techniques. The antibacterial studies of the functionalized MWCNTs against Gram positive and negative bacteria indicated that the MWCNT loaded with complexes exhibited more potent effect than that loaded with ligand only [29]. Finally, the $1: 2$ (M:L) acenaphthaquinone bis(4-allyl thiosemicarbazone) complexes of $\mathrm{Ni}(\mathrm{II}), \mathrm{Cu}(\mathrm{II})$, and $\mathrm{Zn}$ (II) were obtained via onepot synthetic method. The spectral and single crystal X-ray diffraction of the complexes indicated that ligand chelated to metal ion via the azomethine nitrogen and sulfur atom in mononegative bidentate fashion. The $\mathrm{Zn}$ (II) complex was found to be intrinsically fluorescent, so its uptake in IGROV and MCF-7 cancer cells was monitored by confocal fluorescence imaging in addition to comparable cytotoxicity to cisplatin against MCF-7 cell line [30].

Therefore, herein, the synthesis, structure, and cytotoxic activity of a new Schiff base derivative of acenaphthaquinone, $\mathrm{N}$-allyl-2-(2-oxoacenaphthylen-1(2H)-ylidene)hydrazine-1carbothioamide, and its metal complexes were reported.

\section{Experimental}

2.1. Materials and Instrumentation. $N(4)$-allyl-thiosemicarbazide (98.0\%), acenaphthaquinone (99.0 \%), and metal acetate salts were purchased from Fluka, Aldrich, or Merck companies. The hepatocellular carcinoma cell line (HepG2) and normal liver Chang cells were obtained from VACSERA Company. The MTT and RPMI1640 medium were procured from Sigma Company and Fetal Bovine serum from GIBCO.

Elemental analyses were carried out on Perkin-Elmer analyzer 2400 (CHNS). The metal content was obtained by standard methods [31]. The FTIR, ${ }^{1} \mathrm{H}$ NMR, ESR, and UVVis spectra were recorded on ThermoNicolet IS 10, Bruker Ascend $300 \mathrm{MHz}$, Brucker E 500 at $9.808 \mathrm{GHz}, 100 \mathrm{kHz}$ field modulation, and Unicam UV/Vis UV2 spectrometers, respectively. The TG measurement was carried out using Shimadzu model 50 instrument under nitrogen flow $\left(10 \mathrm{~cm}^{3} / \mathrm{min}\right)$ and $15^{\circ} \mathrm{C} / \mathrm{min}$ heating rate. The mass spectra were recorded on a Thermo-Scientific DSQ II spectrometer. The powder X-ray diffraction spectra of the metal complexes were recorded on Bruker AXS D8 Advance diffractometer ( $\mathrm{Cu}-\mathrm{K} \alpha$ radiation of wavelength $\lambda=1.5406 \AA$ source). Magnetic moment measurements were carried out on a Sherwood Scientific magnetic balance. The complexes' molar conductance, $10^{-3} \mathrm{~mol} / \mathrm{l}$ in DMF, was recorded on Tacussel conductivity bridge CD6NG.

2.2. Preparation of $\mathrm{N}$-Allyl-2-(2-oxoacenaphthylen-1(2H)ylidene)hydrazine-1-carbothioamide (HAAT). The reaction of N(4)-allyl-thiosemicarbazide ( $1.31 \mathrm{~g}, 0.01 \mathrm{~mol})$ with acenaphthaquinone $(1.82 \mathrm{~g}, 0.01 \mathrm{~mol})$ in ethanol was refluxed for 2 hours. On cooling to room temperature, a yellow precipitate was observed, filtered off, recrystallized from ethanol, and dried in a vacuum desiccator over anhydrous calcium chloride.

HAAT: N-allyl-2-(2-oxoacenaphthylen-1(2H)-ylidene)hydrazine-1-carbothioamide. Orange, yield 82\%, m.p $195{ }^{\circ} \mathrm{C}$, Anal. Calc. \% for $\mathrm{C}_{16} \mathrm{H}_{13} \mathrm{~N}_{3} \mathrm{OS}$ (295.36): C 65.07; $\mathrm{H} 4.44 ; \mathrm{N}$ 14.23. Found\%: C 65.22; H 4.64; N 14.08. IR $\left(\mathrm{KBr}, \mathrm{cm}^{-1}\right)$ : $3320,3265,1688,1640,936$. UV-Vis $\left(\mathrm{DMF}, \mathrm{cm}^{-1}\right)$ : 35460 , 32890, 28570, 25000, 22830, 21835. 
2.3. Preparation of Solid Complexes. An aqueous solution of metals acetate $(1 \mathrm{mmol})$ was added dropwise to ligand solution $(1 \mathrm{mmol}$, in $\mathrm{EtOH})$. The reaction mixture was refluxed for two hours where the resulting solid complexes were filtered off while being hot, washed successfully with absolute ethanol and diethylether, and finally dried in a desiccator over anhydrous calcium chloride.

[Co(AAT) (OAc) (EtOH)]. Dark brown, yield 70\%, m.p $210{ }^{\circ} \mathrm{C}$, Anal. Calc. \% for $\mathrm{C}_{20} \mathrm{H}_{21} \mathrm{~N}_{3} \mathrm{O}_{4} \mathrm{SCo}$ (458.40): C 52.40; $\mathrm{H}$ 4.62; N 9.17; $\mathrm{M}$ 12.86. Found\%: C 52.12; H 4.38; N 8.97; M 12.73. $\Lambda_{\mathrm{m}}\left(\mathrm{DMSO} \Omega^{-1} \cdot \mathrm{cm}^{2} \cdot \mathrm{mol}^{-1}\right)$ 9.8. IR $\left(\mathrm{KBr}, \mathrm{cm}^{-1}\right): 3314$, $1725,1703,1664,1586,890$. UV-Vis (DMF, $\left.\mathrm{cm}^{-1}\right): 34970$, 32680, 27780, 19160, 17010, 15085.

[Ni(HAAT) $\left.(\mathrm{OAc})_{2}\left(\mathrm{H}_{2} \mathrm{O}\right)\right]$. Brown, yield 73\%, m.p $220^{\circ} \mathrm{C}$, Anal. Calc. \% for $\mathrm{C}_{20} \mathrm{H}_{21} \mathrm{~N}_{3} \mathrm{O}_{6} \mathrm{SNi}$ (490.16): C 49.01; $\mathrm{H} 4.32$; N 8.57; M 11.97. Found\%: C 48.74; H 4.11; N 8.33; M 12.01. $\Lambda_{\mathrm{m}}\left(\mathrm{DMSO} \Omega^{-1} \cdot \mathrm{cm}^{2} \cdot \mathrm{mol}^{-1}\right)$ 10.2. IR $\left(\mathrm{KBr}, \mathrm{cm}^{-1}\right): 3420$, $3336,3279,1702,1652,1619,930$. UV-Vis $\left(\mathrm{DMF}, \mathrm{cm}^{-1}\right)$ : 34965, 32260, 27935, 20160, 19050, 14750.

[Zn $\left.(H A A T)(O A c)_{2}\right]$. Brownish yellow, yield 86\%, m.p $230^{\circ} \mathrm{C}$, Anal. Calc. \% for $\mathrm{C}_{20} \mathrm{H}_{19} \mathrm{~N}_{3} \mathrm{O}_{5} \mathrm{SZn}$ (478.38): C 50.17; $\mathrm{H}$ 4.00; N 8.78; M 13.65. Found\%: C 49.93; H 3.89; N 8.45; M 13.39. $\Lambda_{\mathrm{m}}\left(\mathrm{DMSO} \Omega^{-1} \cdot \mathrm{cm}^{2} \cdot \mathrm{mol}^{-1}\right)$ 10.3. IR $\left(\mathrm{KBr}, \mathrm{cm}^{-1}\right)$ : $3323,3264,1722,1677,1656,1568,935$. UV-Vis (DMF, $\left.\mathrm{cm}^{-1}\right):$ 35210, 32465, 27930, 24390, 21740, 20750.

2.4. Molecular Modeling Method. The ligand and complexes' geometry optimization was performed via the Gaussian 09W suite program [32] at DFT/B3LYP level [33-35] and $6-311++G(d, p)$ basis set. The HOMO-LUMO orbits were demonstrated by the GaussView program [36].

\subsection{Biological Applications}

2.5.1. Antioxidant Activity Screening. The antioxidant activity of the ligand and its complexes was carried out using the ABTS assay procedure $[37,38]$ in which the 2,2 '-azinobis(3-ethylbenzthiazoline-6-sulfonic acid) (ABTS) and L-ascorbic acid serve as free radical source and standard antioxidant, respectively.

2.5.2. In Vitro Antitumor Activity. The hepatocellular carcinoma cell line (HepG2) was used to investigate the anticancer activity by the well-known MTT assay established on the change in color from yellow to purple due to the conversion of tetrazolium bromide (MTT) to formazan derivative in viable cells, and the relative cell viability \% was calculated $[39,40]$. The RPMI-1640 with $10 \%$ fetal bovine serum was utilized as a medium for the culture of the HepG2.

\section{Results and Discussion}

The reaction of HAAT with the $\mathrm{Co}(\mathrm{II}), \mathrm{Ni}(\mathrm{II})$, and $\mathrm{Zn}$ (II) acetate led to the formation of $1: 1$ (M:L) complexes (Table 1). All the isolated solid complexes have nonelectrolytic nature where their molar conductance was 9.8-10.3
$\Omega^{-1} \cdot \mathrm{cm}^{2} \cdot \mathrm{mol}^{-1}[41]$. All isolated solid complexes are soluble only in DMF and DMSO.

3.1. IR Spectra. The HAAT infrared spectrum, in comparison with acenaphthaquinone, presented two new bands at 3320 and $3265 \mathrm{~cm}^{-1}$ attributed to $v\left(\mathrm{~N}^{4} \mathrm{H}\right)$ and $v\left(\mathrm{~N}^{2} \mathrm{H}\right)$ $[27,42]$ vibrations (Figure S1), respectively. Moreover, a sharp band at $1688 \mathrm{~cm}^{-1}$ was assigned to $\nu(\mathrm{C}=\mathrm{O})$ [43] in addition to a new one at $1640 \mathrm{~cm}^{-1}$ attributed to $\nu\left(\mathrm{C}=\mathrm{N}^{1}\right)$ vibration [43] (Figure 1). Furthermore, the new bands observed at $1525,1453,1275$, and $936 \mathrm{~cm}^{-1}$ were assigned to thioamide I, II, III, and $\nu(\mathrm{C}=\mathrm{S})[27,44]$, respectively. The bands observed at 3048, 3029, 2969, and $2955 \mathrm{~cm}^{-1}$ were attributed to $\nu_{\mathrm{s}}(\mathrm{CH})$ and $\nu_{\mathrm{as}}(\mathrm{CH})$ [44] vibrations of aromatic and allyl moieties (Table 2), respectively.

The comparison between ligand and [Co(AAT) (OAc) $\left.\left(\mathrm{H}_{2} \mathrm{O}\right)\right]$ spectral data revealed that HAAT chelated with the metal ion in a mononegative tridentate fashion via the carbonyl oxygen, azomethine nitrogen, and sulfur atom of deprotonated thiol ( $\mathrm{SH}$ ) (Figure 2) where we have the following:

(i) Only one band centered at $3314 \mathrm{~cm}^{-1}$ due to $\nu\left(\mathrm{N}^{4} \mathrm{H}\right)$ vibrations [45] was observed

(ii) The disappearance of vibrational bands due to the $v\left(\mathrm{~N}^{2} \mathrm{H}\right)$ and $\nu(\mathrm{C}=\mathrm{S})$ along with the appearance of two new bands at 1622 and $890 \mathrm{~cm}^{-1}$ attributed to the newly formed azomethine $v\left(\mathrm{C}=\mathrm{N}^{2}\right)[42,45]$ and $\nu(\mathrm{C}-\mathrm{S})[45,46]$ designated that the ligand transformed into thiol form. Meanwhile, the absence of $\nu(\mathrm{SH})$ vibrational band, $2500-2600 \mathrm{~cm}^{-1}$ range, endorsed that the newly formed $\mathrm{SH}$ group deprotonated when the ligand reacted with the metal ion $[42,43]$ (Figure S2). Both thioamide nitrogen atoms $\mathrm{N}^{2}$ and $\mathrm{N}^{4}$ were subjected to electron-withdrawing inductive effect with possible delocalization from the thione carbon atom, poorer in electron density. But the azomethine nitrogen atom $\mathrm{N}^{1}$ exerted electron release inductive effect without delocalization possibility on the adjacent $\mathrm{N}^{2}$ which led to the fact that the $\mathrm{N}^{2}$ restored some of its electron density and thus became more suitable for involvement in the enolization process [47]

(iii) The shift to the higher wavenumber of both $v(\mathrm{C}=\mathrm{O})$ and $\nu\left(\mathrm{C}=\mathrm{N}^{1}\right)$ vibrational bands, observed at 1703 and $1664 \mathrm{~cm}^{-1}$, respectively, revealed their involvement in coordination with the metal ion

(iv) Finally, new bands at 1725 and $1586 \mathrm{~cm}^{-1}$ were attributed to $v_{\text {as }}(\mathrm{OAc})$ and $v_{\mathrm{s}}(\mathrm{OAc})$ vibrations, respectively, of coordinated acetate ion in bidentate fashion (difference $\approx 139 \mathrm{~cm}^{-1}$ ) $[45,48]$. The new bands observed at 530 and $494 \mathrm{~cm}^{-1}$ were attributed to $v(\mathrm{M}-\mathrm{O})$ in addition to a band at $478 \mathrm{~cm}^{-1}$ which was assigned to $v(\mathrm{M}-\mathrm{N})[45,49]$

The IR spectral data of [Ni(HAAT) $\left.(\mathrm{OAc})_{2}\left(\mathrm{H}_{2} \mathrm{O}\right)\right]$ complex displayed two bands at 3336 and $3279 \mathrm{~cm}^{-1}$, assigned to the $v\left(\mathrm{~N}^{4} \mathrm{H}\right)$ and $\nu\left(\mathrm{N}^{2} \mathrm{H}\right)$ vibrations [43, 45], 
TABLE 1: Analytical and physical data of HAAT and its complexes.

\begin{tabular}{|c|c|c|c|c|c|c|c|}
\hline \multirow{2}{*}{ Compound (mol. formula; Wt.) } & \multirow{2}{*}{ Color } & \multirow{2}{*}{$\begin{array}{l}\text { m.p. } \\
\left({ }^{\circ} \mathrm{C}\right)\end{array}$} & \multicolumn{4}{|c|}{ Elemental analyses; found (calcd.) } & \multirow{2}{*}{$\Lambda_{\mathrm{m}}$} \\
\hline & & & $\mathrm{C}$ & $\mathrm{H}$ & $\mathrm{N}$ & M & \\
\hline $\operatorname{HAAT}\left(\mathrm{C}_{16} \mathrm{H}_{13} \mathrm{~N}_{3} \mathrm{OS} ; 295.36\right)$ & Orange & 195 & $\begin{array}{c}65.22 \\
(65.07)\end{array}$ & $\begin{array}{c}4.64 \\
(4.44)\end{array}$ & $\begin{array}{c}14.08 \\
(14.23)\end{array}$ & - & - \\
\hline $\begin{array}{l}{[\mathrm{Co}(\mathrm{AAT})(\mathrm{OAc})(\mathrm{EtOH})]\left(\mathrm{C}_{20} \mathrm{H}_{21} \mathrm{~N}_{3} \mathrm{O}_{4} \mathrm{SCo} ;\right.} \\
458.40)\end{array}$ & Dark brown & 210 & $\begin{array}{c}52.12 \\
(52.40)\end{array}$ & $\begin{array}{c}4.38 \\
(4.62)\end{array}$ & $8.97(9.17)$ & $\begin{array}{c}12.73 \\
(12.86)\end{array}$ & 9.8 \\
\hline $\begin{array}{l}{\left[\mathrm{Ni}(\mathrm{HAAT})(\mathrm{OAc})_{2}\left(\mathrm{H}_{2} \mathrm{O}\right)\right]\left(\mathrm{C}_{20} \mathrm{H}_{21} \mathrm{~N}_{3} \mathrm{O}_{6} \mathrm{SNi}\right.} \\
490.16)\end{array}$ & Brown & 220 & $\begin{array}{c}48.74 \\
(49.01)\end{array}$ & $\begin{array}{c}4.11 \\
(4.32)\end{array}$ & $8.33(8.57)$ & $\begin{array}{l}12.01 \\
(11.97)\end{array}$ & 10.2 \\
\hline$\left[\mathrm{Zn}(\mathrm{HAAT})(\mathrm{OAc})_{2}\right]\left(\mathrm{C}_{20} \mathrm{H}_{19} \mathrm{~N}_{3} \mathrm{O}_{5} \mathrm{SZn} ; 478.38\right)$ & $\begin{array}{l}\text { Brownish } \\
\text { yellow }\end{array}$ & 230 & $\begin{array}{c}49.93 \\
(50.17)\end{array}$ & $\begin{array}{c}3.89 \\
(4.00)\end{array}$ & $8.45(8.78)$ & $\begin{array}{l}13.39 \\
(13.65)\end{array}$ & 10.3 \\
\hline
\end{tabular}

${ }^{*}$ Measured in DMSO $\Omega^{-1} \cdot \mathrm{cm}^{2} \cdot \mathrm{mol}^{-1}$.

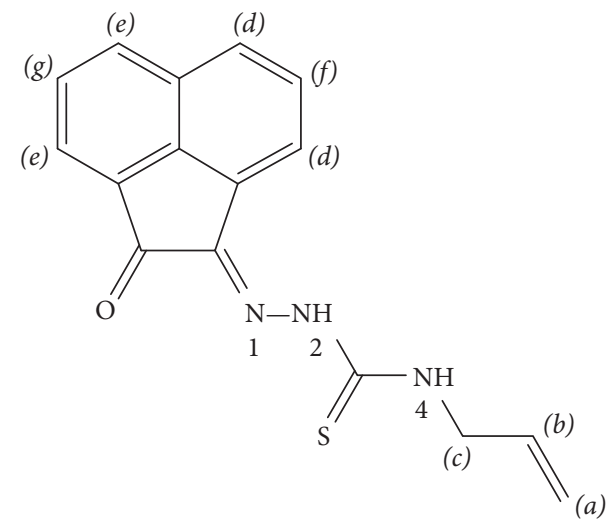

Figure 1: Structure of HAAT.

TABLE 2: Infrared spectral date of HAAT and its metal complexes.

\begin{tabular}{lcccc}
\hline Vibration & HAAT & Ni(II) & Co(II $)$ & Zn(II $)$ \\
\hline$\nu(\mathrm{OH})_{\text {solv. }}$ & - & 3420 & 3425 & - \\
$\nu\left(\mathrm{N}^{4} \mathrm{H}\right)$ & 3320 & 3336 & 3314 & 3323 \\
$\nu\left(\mathrm{N}^{2} \mathrm{H}\right)$ & 3265 & 3279 & - & 3264 \\
$\nu(\mathrm{CH})_{\text {Ar. }}$ & 3048,2955 & 3070,2955 & 3060,2957 & 3050,2958 \\
$\nu(\mathrm{CH})_{\text {Allyl }}$ & 3029,2969 & 3020,2922 & 3030,2918 & 3018,2920 \\
$\nu(\mathrm{C}=\mathrm{O})_{\text {OAc }}$ & - & 1702,1390 & 1725,1586 & 1722,1568 \\
$\nu(\mathrm{C}=\mathrm{O})$ & 1688 & 1652 & 1703 & 1677 \\
$\nu(\mathrm{C}=\mathrm{N})$ & 1640 & 1619 & 1664 & 1656 \\
$\nu(\mathrm{C}=\mathrm{C})_{\text {Ar }}$ & 1607 & 1602 & 1601 & 1604 \\
Thioamide I & 1525 & 1520 & 1513 & 1524 \\
Thioamide II & 1453 & 1466 & 1467 & 1451 \\
Thioamide III & 1275 & 1251 & 1234 & 1250 \\
$\nu(\mathrm{N}-\mathrm{N})$ & 1146 & 1172 & 1117 & 1175 \\
$\nu(\mathrm{C}-\mathrm{O})$ & 1052 & 1092 & 1080 & 1083 \\
$\nu(\mathrm{C}=\mathrm{S})$ & 936 & 930 & $890(\mathrm{C}-\mathrm{S})$ & 935 \\
$\rho(\mathrm{NH})$ & 794 & 775 & 775 & 775 \\
$\nu(\mathrm{M}-\mathrm{O})$ & - & 528,500 & 530,494 & 526,492 \\
$\nu(\mathrm{M}-\mathrm{N})$ & - & 477 & 478 & 482 \\
\hline
\end{tabular}

respectively (Table 2). Furthermore, the spectrum exhibited three bands at 1652,1619 , and $930 \mathrm{~cm}^{-1}$ attributed to $\nu(\mathrm{C}=\mathrm{O}), \nu\left(\mathrm{C}=\mathrm{N}^{1}\right)$, and $\nu(\mathrm{C}=\mathrm{S})[45,46]$ vibrations, respectively (Figure S3). Moreover, two new bands were observed at 1702 and $1390 \mathrm{~cm}^{-1}$ and were assigned to $v_{\text {as }}(\mathrm{OAc})$ and $v_{s}(\mathrm{OAc})$ vibrations, respectively, of coordinated acetate ion in a monodentate fashion (difference $\approx 312 \mathrm{~cm}^{-1}$ ) $[45,48]$. The new bands at 528 and $500 \mathrm{~cm}^{-1}$ were attributed to $v(\mathrm{M}$ $\mathrm{O}$ ) in addition to a band at $477 \mathrm{~cm}^{-1}$ which was assigned to $\nu(\mathrm{M}-\mathrm{N})[45,49]$. Comparison with the ligand spectral data cleared that the bands due to $v(\mathrm{C}=\mathrm{O}), v(\mathrm{C}=\mathrm{N})$, and $v(\mathrm{C}=\mathrm{S})$ vibrations were shifted to lower wavenumber which indicated their participation in coordination with the metal ion. Hence, the ligand chelated with the metal ion as neutral tridentate via NOS atoms (Figure 3).

Finally, the spectrum of [ $\left.\mathrm{Zn}(\mathrm{HAAT})(\mathrm{OAc})_{2}\right]$ complex presented $v\left(\mathrm{~N}^{4} \mathrm{H}\right), v\left(\mathrm{~N}^{2} \mathrm{H}\right)$, and $\nu(\mathrm{C}=\mathrm{S})$ vibrational bands at 3323,3264 , and $935 \mathrm{~cm}^{-1}[43,45]$, respectively, which are almost at the same position exhibited in ligand spectrum and so endorsed that they are free (Table 2). Additionally, the spectrum showed two bands at 1677 and $1656 \mathrm{~cm}^{-1}$ ascribed to $\nu(\mathrm{C}=\mathrm{O})$ and $\nu\left(\mathrm{C}=\mathrm{N}^{1}\right)[45,46]$ vibrations, respectively. The new bands at 1722 and $1568 \mathrm{~cm}^{-1}$ were assigned to $\nu_{\text {as }}(\mathrm{OAc})$ and $v_{s}(\mathrm{OAc})$ vibrations, respectively, of bidentate acetate ion (difference $\approx 154 \mathrm{~cm}^{-1}$ ) $[45,48]$. The new bands observed at 526 and $492 \mathrm{~cm}^{-1}$ were attributed to $\nu(\mathrm{M}-\mathrm{O})$ in addition to a band at $482 \mathrm{~cm}^{-1}$ which was assigned to $v(\mathrm{M}-\mathrm{N})[45,49]$. Accordingly, the data revealed that $\nu(\mathrm{C}=\mathrm{O})$ and $\nu\left(\mathrm{C}=\mathrm{N}^{1}\right)$ bands were shifted to lower or higher wavenumber, with respect to the ligand, which designated their participation in coordination with the metal ion as neutral bidentate via NO atoms (Figure 4).

3.2. ${ }^{1} \mathrm{H}$ NMR Spectral Data. The ligand ${ }^{1} \mathrm{H}-\mathrm{NMR}$ spectrum, in $\mathrm{DMSO}-\mathrm{d}_{6}$, displayed singlet signals at 12.65 and $9.55 \mathrm{ppm}$ due to $\mathrm{N}^{4} \mathrm{H}$ and $\mathrm{N}^{2} \mathrm{H}$ protons $[27,44]$, respectively (Figure 1). As well, to confirm assignment, the addition of $\mathrm{D}_{2} \mathrm{O}$ solution led to the disappearance of these two signals (Figure 5(a)). Furthermore, the spectrum displayed two doublet signals at 8.37 and $8.10 \mathrm{ppm}$ in addition to two multiplet signals at 8.03 and $7.86 \mathrm{ppm}$ assigned to the acenaphthaquinone protons at positions $(d),(e),(f)$, and $(g)$ $[27,44]$, respectively. In addition, three signals were observed at $5.96,5.19$, and $4.31 \mathrm{ppm}$ and were attributed to $(\mathrm{CH})_{\text {ally }},\left(\mathrm{CH}_{2}\right)_{\text {allyl }}$, and $\mathrm{CH}_{2}$ protons [44, 46], respectively.

The spectrum of $\mathrm{Zn}$ (II) complex in $\mathrm{d}_{6}$-DMSO, compared to the ligand, displayed the singlet signals of both $\mathrm{N}^{4} \mathrm{H}$ and $\mathrm{N}^{2} \mathrm{H}$ at 12.65 and $9.55 \mathrm{ppm}[27,44]$, the same positions shown in the ligand spectrum, which confirmed that they are free and the ligand existed in a thione form (Figure 5(b)). 


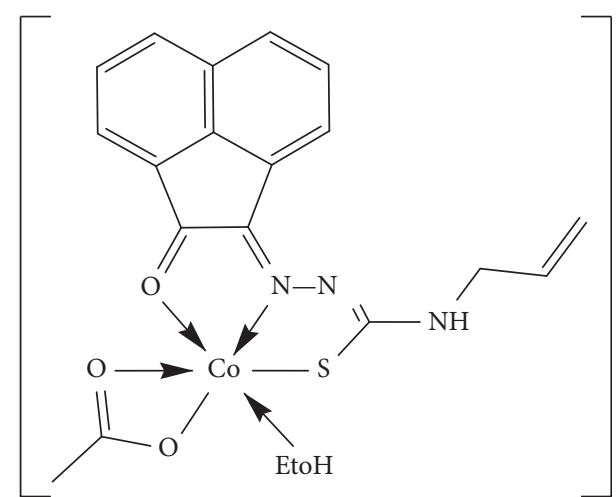

FIGURE 2: Suggested structure of Co(II) complex.

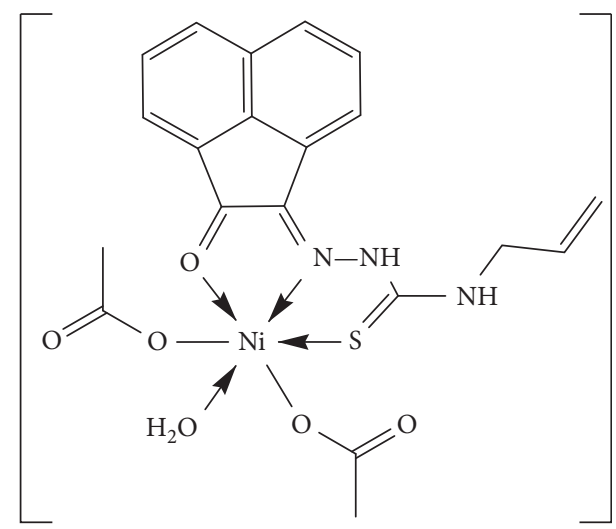

Figure 3: Suggested structure of Ni(II) complex.

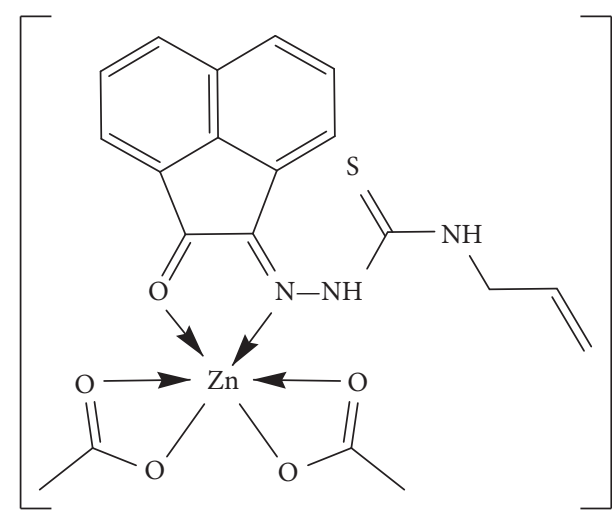

Figure 4: Suggested structure of Zn(II) complex.

Additionally, the spectrum showed the acenaphthaquinone protons as doublet signals at 8.38 and 8.11 in addition to two multiplet signals at 7.99 and $7.82 \mathrm{ppm}$ corresponding to the positions $(d),(e),(f)$, and $(g)[27,44]$, respectively. The signals due to $(\mathrm{CH})_{\text {allyl }},\left(\mathrm{CH}_{2}\right)_{\text {ally }}$, and $\mathrm{CH}_{2}$ protons were observed at 5.95, 5.21, and $4.32 \mathrm{ppm}[44,46]$, respectively.

3.3. Mass Spectra. The HAAT mass spectrum confirmed the proposed molecular formula as it showed a molecular ion peak at $m / z=295(22.95 \%)$ that was coincided with its molecular weight (295.36) (Figure 6). The spectrum showed a weak peak at $m / z=280(5.99 \%)$ which may be due to the loss of methyl radical from the allyl moiety, ${ }^{\circ} \mathrm{CH}_{3}$ (Route I), or oxygen atom of the carbonyl group, ${ }^{\circ} \mathrm{O}$ (Route II), as shown in the fragmentation pattern (Scheme 1). Another peak observed at $m / z=254$ and attributed to $\mathrm{C}_{13} \mathrm{H}_{8} \mathrm{~N}_{3} \mathrm{OS}^{\bullet}$ and $\mathrm{C}_{14} \mathrm{H}_{12} \mathrm{~N}_{3} \mathrm{~S}^{\bullet}$ formulae in routes I and II, respectively, resulted from the loss of ${ }^{\bullet} \mathrm{C}_{2} \mathrm{H}_{2}$ moiety in both routes. The observed peak at $m / z=239$ was ascribed to loss of ${ }^{\circ} \mathrm{NH}$ and ${ }^{\circ} \mathrm{CH}_{3}$ radicals that led to the formation of $\mathrm{C}_{13} \mathrm{H}_{7} \mathrm{~N}_{2} \mathrm{OS}^{\bullet}$ and $\mathrm{C}_{13} \mathrm{H}_{9} \mathrm{~N}_{3} \mathrm{~S}^{\bullet}$ moieties (F. Wt. 239.03 and 239.05) in routes I and II, respectively. Furthermore, the spectrum exhibited a base peak at $\mathrm{m} / z=180(100 \%)$ corresponding to the formula $\mathrm{C}_{12} \mathrm{H}_{6} \mathrm{NO}^{\bullet}(180.04)$ and $\mathrm{C}_{12} \mathrm{H}_{8} \mathrm{~N}_{2}{ }^{\bullet+}$ (180.07) in routes I and II, respectively (Scheme 1).

On the other hand, the $\mathrm{Co}(\mathrm{II}), \mathrm{Ni}(\mathrm{II})$, and $\mathrm{Zn}(\mathrm{II})$ complexes' mass spectra showed quite a lot of peaks where the most important one was the molecular ion peak that was observed at $458.37(2.08 \%), 490.04(3.54 \%)$, and 478.17 $(0.75 \%)$, respectively, coincided with the proposed formulae of the complexes (Figures S4-S6). For instance, the Co(II) complex spectrum showed the molecular ion peak at $\mathrm{m} /$ $z=458$ corresponding to the suggested formula [Co(AAT) $(\mathrm{OAc})(\mathrm{EtOH})](\mathrm{M} . \mathrm{Wt} .=458.40)$. The observed peak at $\mathrm{m} /$ $z=412.02(1.92 \%)$ was attributed to the fact that the complex lost ethanol molecule leading to $[\mathrm{Co}(\mathrm{AAT})(\mathrm{OAc})]^{\bullet+}$ formula, $\mathrm{C}_{18} \mathrm{H}_{15} \mathrm{CoN}_{3} \mathrm{O}_{3} \mathrm{~S}^{\bullet+}(\mathrm{F}$. Wt. $=412.33)$. The spectrum displayed another peak at $m / z=368.43(2.18 \%)$ assigned to the $\mathrm{C}_{15} \mathrm{H}_{7} \mathrm{CoN}_{3} \mathrm{O}_{3} \mathrm{~S}^{\bullet+}$ formula (F. Wt. $=368.23$ ) that resulted from the degradation of the ligand and acetate ion by losing the $\mathrm{C}_{3} \mathrm{H}_{8}$ fragment.

\subsection{Electronic Spectra and Magnetic Moment Measurements.} The electronic spectrum of the ligand, in DMF, showed two bands at 35460 and $28570 \mathrm{~cm}^{-1}$ with a shoulder at $32890 \mathrm{~cm}^{-1}$ attributable to the $\pi \longrightarrow \pi^{*}$ transition of aromatic acenaphthaquinone moiety, carbonyl group, and both of azomethine and thione groups [44], respectively (Table 3). Moreover, the spectrum displayed a broad band at $21835 \mathrm{~cm}^{-1}$ with two shoulders at 22830 and $25000 \mathrm{~cm}^{-1}$ assigned to the $n \longrightarrow \pi^{*}$ transitions of thione, azomethine, and carbonyl groups $[44,48]$, respectively (Figure S7(a)).

The Co(II) complex spectrum, in DMF, exhibited a band at $17010 \mathrm{~cm}^{-1}$ with a shoulder at $15085 \mathrm{~cm}^{-1}$ designated to ${ }^{4} \mathrm{~T}_{1 \mathrm{~g}}(\mathrm{~F}) \longrightarrow{ }^{4} \mathrm{~T}_{1 \mathrm{~g}}(\mathrm{P})\left(v_{3}\right)$ and ${ }^{4} \mathrm{~T}_{1 \mathrm{~g}}(\mathrm{~F}) \longrightarrow{ }^{4} \mathrm{~A}_{2 \mathrm{~g}}(\mathrm{P})\left(v_{2}\right)$ transitions [50], respectively, for octahedral configuration of $\mathrm{Co}(\mathrm{II})$ ion (Figure S7(b)). The $\mathrm{d}^{7}$-system parameters, $v_{1}, \mathrm{~B}$, and $10 \mathrm{Dq}$, were calculated via the spin allowed transitions, $v_{3}$ and $v_{2}$, and were 7049,729 , and $8020 \mathrm{~cm}^{-1}$, respectively, confirming the octahedral arrangement $[43,50]$. Furthermore, the spectrum displayed two new bands at 20410 and $19160 \mathrm{~cm}^{-1}$ attributed to the charge transfer from ligand to metal (LMCT) and $n \longrightarrow \pi^{*}$ transition of the newly formed azomethine group $\left(\mathrm{C}=\mathrm{N}^{2}\right)$ confirming the ligand existence in thiol form (Table 3). The shift of carbonyl and azomethine $n \longrightarrow \pi^{*}$ transition supported its participation in coordination with the metal ion $[46,51]$. Finally, the color and magnetic moment value of the $\mathrm{Co}$ (II) complex, dark brown 


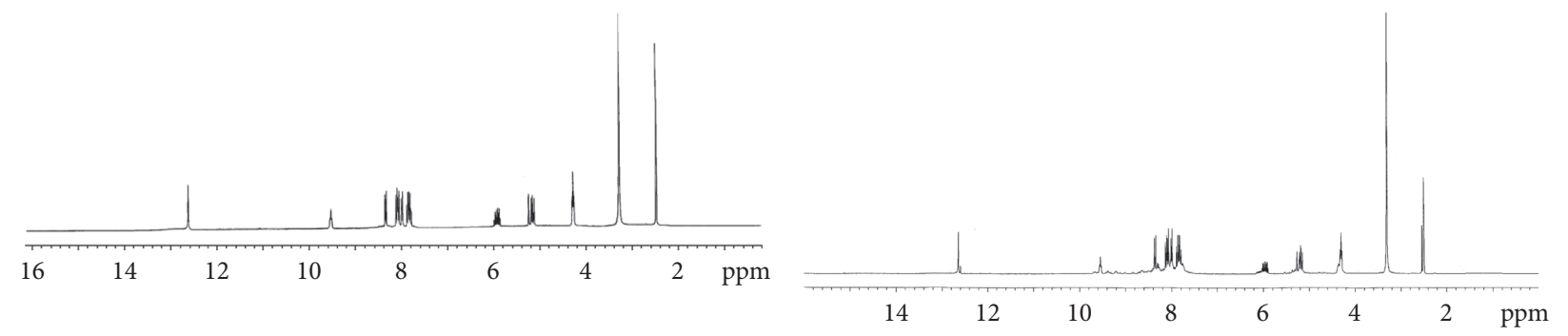

(a)

(b)

Figure 5: ${ }^{1} \mathrm{H}$ NMR spectra of HAAT (a) and $\mathrm{Zn}(\mathrm{II})$ complex (b) in DMSO- $\mathrm{d}_{6}$.

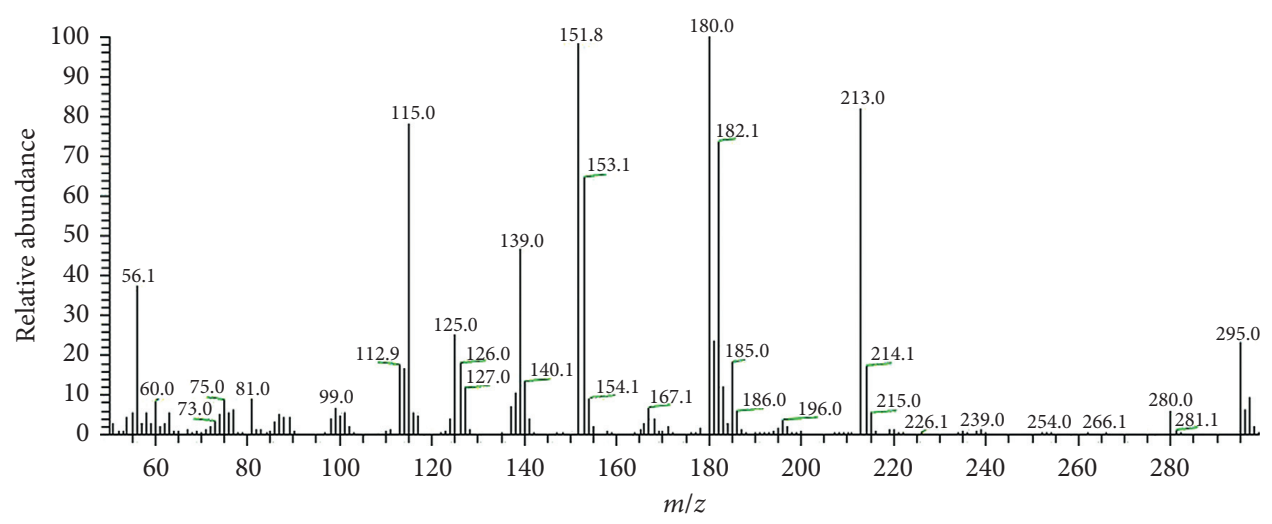

Figure 6: Mass spectrum of HAAT.

and 5.00 B.M., offered further confirmation for the octahedral structure $[46,50,51]$.

The Ni(II) complex displayed two bands at 34965 and $27935 \mathrm{~cm}^{-1}$ with a shoulder at $32260 \mathrm{~cm}^{-1}$ attributed to the intraligand transitions, $\left(\pi \longrightarrow \pi^{*}\right)_{\mathrm{Acen}},\left(\pi \longrightarrow \pi^{*}\right)_{\mathrm{CN} \& \mathrm{CS}}$, and $\left(\pi \longrightarrow \pi^{*}\right)_{\mathrm{CO}}[44,48]$, respectively. Moreover, the shoulders observed at 25315,22525 , and $21645 \mathrm{~cm}^{-1}$ were assigned to $n \longrightarrow \pi^{*}$ transitions of the carbonyl, azomethine, and thione groups $[44,48]$, respectively. The comparison with the ligand spectral data revealed that they were shifted to higher or lower wavenumbers, which confirmed their participation in coordination with the metal ion [50]. Furthermore, a new band was observed at $20160 \mathrm{~cm}^{-1}$ with two shoulders at 19050 and $14750 \mathrm{~cm}^{-1}$ ascribed to the LMCT, ${ }^{3} \mathrm{~A}_{2 \mathrm{~g}} \longrightarrow{ }^{3} \mathrm{~T}_{1 \mathrm{~g}}(\mathrm{~F})\left(\nu_{2}\right)$ and ${ }^{3} \mathrm{~A}_{2 \mathrm{~g}}(\mathrm{~F}) \longrightarrow{ }^{3} \mathrm{~T}_{2 \mathrm{~g}}(\mathrm{~F})\left(\nu_{1}\right)$ transitions, respectively, suggesting that the $\mathrm{Ni}$ (II) complex has an octahedral geometry $[48,50]$. The spin allowed transitions of the $\mathrm{d}^{8}$-system were employed to determine $v_{3}, \mathrm{~B}$, and $\mathrm{Dq}$ parameters and were 31195,399 , and $1476 \mathrm{~cm}^{-1}$, respectively. The magnetic moment value was 3.09 B.M. supporting the suggestion of an octahedral structure with ${ }^{3} \mathrm{~A}_{2 \mathrm{~g}}$ ground term $[48,50]$.

Finally, the $\mathrm{Zn}$ (II) complex displayed two bands at 35210 and $27930 \mathrm{~cm}^{-1}$ with a shoulder at $32265 \mathrm{~cm}^{-1}$ attributed to the intraligand transitions, $\left(\pi \longrightarrow \pi^{*}\right.$ Acen, $\left(\pi \longrightarrow \pi^{*}\right)_{\mathrm{CN} \& \mathrm{CS}}$, and $\left(\pi \longrightarrow \pi^{*}\right)_{\mathrm{CO}}[44,48]$, respectively. Moreover, the band at $20750 \mathrm{~cm}^{-1}$ with shoulders at 24390 , 22420 , and $21740 \mathrm{~cm}^{-1}$ was assigned LMCT, $\left(n \longrightarrow \pi^{*}\right)_{\mathrm{CO}}$, $\left(n \longrightarrow \pi^{*}\right)_{\mathrm{CN}}$, and $\left(n \longrightarrow \pi^{*}\right)_{\mathrm{CS}}$ transitions $[44,48]$, respectively. The data showed that both carbonyl and azomethine $n \longrightarrow \pi^{*}$ transition bands were shifted to higher or lower wavenumbers supporting their involvement in the metal ion chelation [50].

3.5. Thermal Analyses. The thermogravimetric analyses of the ligand and isolated solid complexes confirmed the existence of $\mathrm{H}_{2} \mathrm{O}$ and/or EtOH molecules whichever outside or inside the chelation sphere.

The thermal analysis curve of HAAT showed two decomposition steps at the $150-380$ and $380-715^{\circ} \mathrm{C}$ range. The first step was attributed to the loss of the thione and allyl groups, $\mathrm{C}_{4} \mathrm{H}_{6} \mathrm{NS}$ (Found: $34.44 \%$; Calcd.: $34.35 \%$ ), while the second step corresponded to the complete decomposition of the ligand (Found: 61.35\%; Calcd.: 61.63\%) leading to a carbon ash residue (Found: 4.21\%; Calcd.: 4.12\%) (Figure S8).

The Co(II) and $\mathrm{Zn}$ (II) complexes' TG curves displayed only two successive decomposition stages over 125-445 and $445-610^{\circ} \mathrm{C}$ ranges. The first stage of the $\mathrm{Co}(\mathrm{II})$ complex was due to the loss of coordinated ethanol molecule and acetate anion (Found: $22.12 \%$; Calcd.: $22.92 \%$ ) while that of $\mathrm{Zn}$ (II) was due to the loss of the acetate anions (Found: $25.01 \%$; Calcd.: $24.66 \%$ ). The second stage in both complexes was attributed to complete decomposition of the ligand leading to a residue of metallic residue (Found: 12.95 and $13.80 \%$; Calcd.: 12.86 and $13.65 \%$, for $\mathrm{Co}(\mathrm{II})$ and $\mathrm{Zn}$ (II) complexes, respectively) (Table 4). 


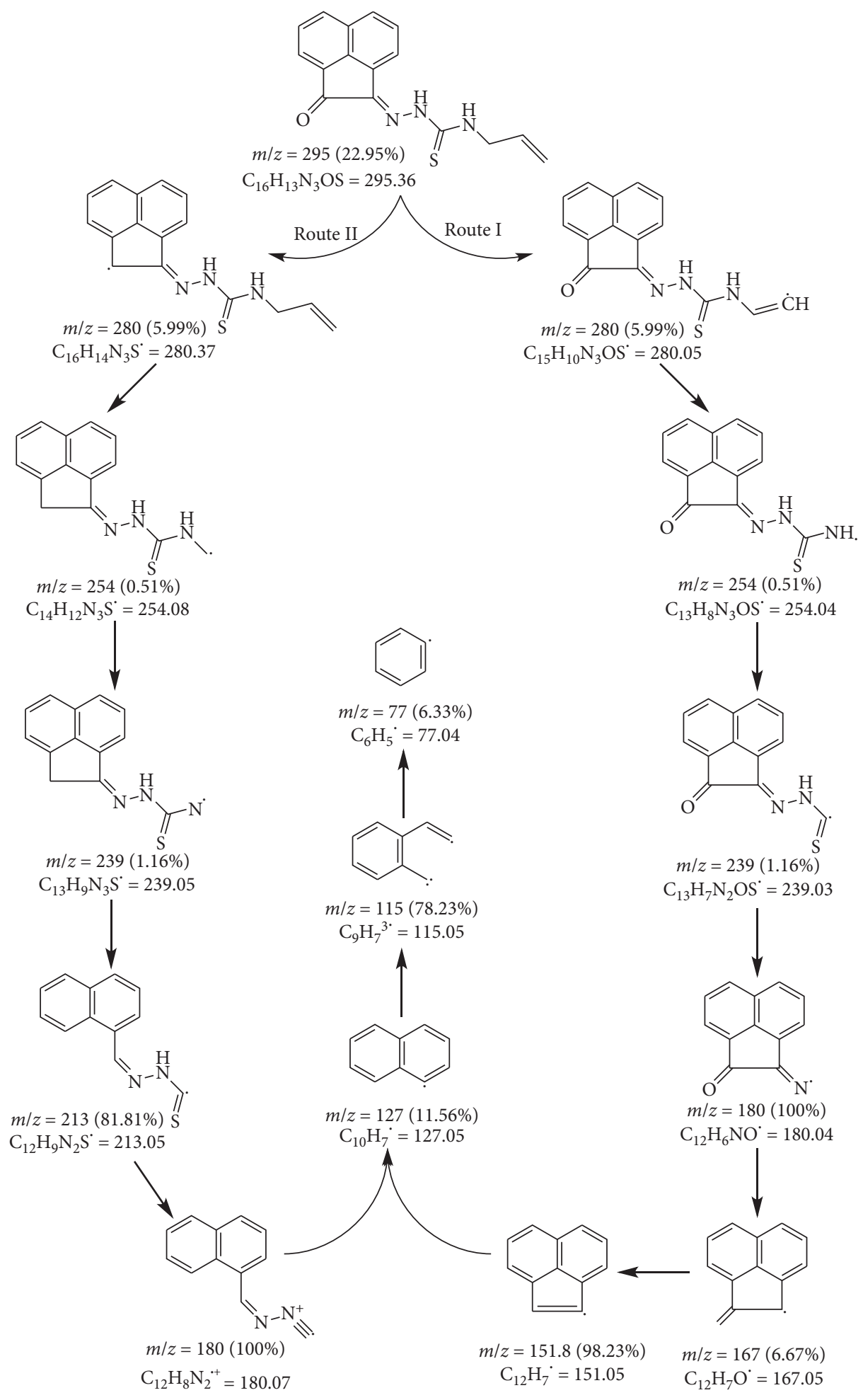

Scheme 1: Fragmentation pattern of HAAT.

Finally, the curve of the Ni(II) complex showed that it has thermal stability up to $155^{\circ} \mathrm{C}$ at which the first decomposition step was observed and attributed to the loss of the coordinated water molecule and acetate anions (Found: 28.01\%; Calcd.: 27.75\%). The second step was observed over the $390-455^{\circ} \mathrm{C}$ range and corresponds to the loss of $\mathrm{C}_{3} \mathrm{H}_{6} \mathrm{~N}$ moiety (Found: $11.78 \%$; Calcd.: $11.44 \%$ ). The third degradation step was extended from $455^{\circ} \mathrm{C}$ to $640^{\circ} \mathrm{C}$ and attributed to complete decomposition of the ligand (Found: 48.90\%; Calcd.: 48.84\%) leaving a metallic residue of nickel metal (Found: 11.31\%; Calcd.: 11.97\%) (Figure S9). 
TABLE 3: Electronic spectral date of AATH and its metal complexes.

\begin{tabular}{|c|c|c|}
\hline Compound & Transitions & $\mu_{\text {eff. }}$ \\
\hline HAAT & $\begin{array}{c}35460\left(\pi \longrightarrow \pi^{*}\right)_{\text {Acen }}, 32890\left(\pi \longrightarrow \pi^{*}\right)_{\mathrm{CO}}, 28570\left(\pi \longrightarrow \pi^{*}\right)_{\mathrm{CN} \& \mathrm{CS}}, 25000\left(n \longrightarrow \pi^{*}\right)_{\mathrm{CO}}, 22830\left(n \longrightarrow \pi^{*}\right)_{\mathrm{CN}} \\
21835\left(n \longrightarrow \pi^{*}\right)_{\mathrm{CS}}\end{array}$ & \\
\hline $\begin{array}{l}{[\mathrm{Co}(\mathrm{AAT})(\mathrm{OAc})} \\
\left.\left(\mathrm{H}_{2} \mathrm{O}\right)\right]\end{array}$ & $\begin{array}{l}34970\left(\pi \longrightarrow \pi^{*}\right)_{\text {Acen }}, 32680\left(\pi \longrightarrow \pi^{*}\right)_{\mathrm{CO}}, 27780\left(\pi \longrightarrow \pi^{*}\right)_{\mathrm{CN} \& \mathrm{CS}}, 25380\left(n \longrightarrow \pi^{*}\right)_{\mathrm{CO}}, 22320\left(n \longrightarrow \pi^{*}\right)_{\mathrm{CN}} \\
\quad 20410\left(n \longrightarrow \pi^{*}\right)_{\mathrm{CN}}{ }^{2}, 19160(\mathrm{LMCT}), 17010{ }^{4} \mathrm{~T}_{1 \mathrm{~g}}(\mathrm{~F}) \longrightarrow{ }^{4} \mathrm{~T}_{1 \mathrm{~g}}(\mathrm{P})\left(v_{3}\right), 15085{ }^{4} \mathrm{~T}_{1 \mathrm{~g}}(\mathrm{~F}) \longrightarrow{ }^{4} \mathrm{~A}_{2 \mathrm{~g}}(\mathrm{P})\left(v_{2}\right)\end{array}$ & 5.00 \\
\hline $\begin{array}{l}{[\mathrm{Ni}(\mathrm{HAAT})} \\
\left.(\mathrm{OAc})_{2}\left(\mathrm{H}_{2} \mathrm{O}\right)\right]\end{array}$ & $\begin{array}{l}34965\left(\pi \longrightarrow \pi^{*}\right)_{\text {Acen }}, 32260\left(\pi \longrightarrow \pi^{*}\right)_{\mathrm{CO}}, 27935\left(\pi \longrightarrow \pi^{*}\right)_{\mathrm{CN} \& \mathrm{CS}}, 25315\left(n \longrightarrow \pi^{*}\right)_{\mathrm{CO}}, 22525\left(n \longrightarrow \pi^{*}\right)_{\mathrm{CN}} \\
21645\left(n \longrightarrow \pi^{*}\right)_{\mathrm{CS}}, 20160(\mathrm{LMCT}), 19050{ }^{3} \mathrm{~A}_{2 \mathrm{~g}} \longrightarrow{ }^{3} \mathrm{~T}_{1 \mathrm{~g}}(\mathrm{~F})\left(\nu_{2}\right), 14750{ }^{3} \mathrm{~A}_{2 \mathrm{~g}}(\mathrm{~F}) \longrightarrow \mathrm{T}_{2 \mathrm{~g}}(\mathrm{~F})\left(v_{1}\right)\end{array}$ & 3.09 \\
\hline$\left[\mathrm{Zn}(\mathrm{HAAT})(\mathrm{OAc})_{2}\right]$ & $\begin{aligned} 35210\left(\pi \longrightarrow \pi^{*}\right)_{\text {Acen }}, 32465\left(\pi \longrightarrow \pi^{*}\right)_{\mathrm{CO}}, 27930\left(\pi \longrightarrow \pi^{*}\right)_{\mathrm{CN} \& \mathrm{CS}}, 24390\left(n \longrightarrow \pi^{*}\right)_{\mathrm{CO}}, 22420\left(n \longrightarrow \pi^{*}\right)_{\mathrm{CN}}, \\
21740\left(n \longrightarrow \pi^{*}\right)_{\mathrm{CS},} 20750(\mathrm{LMCT})\end{aligned}$ & - \\
\hline
\end{tabular}

TABLe 4: Thermal gravimetric analysis of HAAT and its complexes.

\begin{tabular}{|c|c|c|c|c|}
\hline \multirow{2}{*}{ Compound } & \multirow{2}{*}{ Temp. range $\left({ }^{\circ} \mathrm{C}\right)$} & \multicolumn{2}{|c|}{ Wt. loss $\%$} & \multirow{2}{*}{ Fragment lost } \\
\hline & & Found & Calcd. & \\
\hline \multirow{3}{*}{ HAAT } & $150-380$ & 34.44 & 34.25 & $\mathrm{HCNS}+\mathrm{CH}_{3} \mathrm{CH}=\mathrm{CH}_{2}$ \\
\hline & $380-715$ & 61.35 & 61.63 & $\mathrm{C}_{11} \mathrm{H}_{6} \mathrm{~N}_{2} \mathrm{O}$ \\
\hline & Residue & 4.21 & 4.12 & Carbon ash \\
\hline \multirow{3}{*}[\mathrm{Co}(\mathrm{AAT})(\mathrm{OAc})(\mathrm{H}_{2}\mathrm{O})]{} & $180-445$ & 22.56 & 22.93 & $\mathrm{OAc}+\mathrm{EtOH}$ \\
\hline & $445-620$ & 60.93 & 60.73 & $\mathrm{C}_{16} \mathrm{H}_{12} \mathrm{~N}_{3} \mathrm{~S}$ \\
\hline & Residue & 16.51 & 16.35 & $\mathrm{CoO}$ \\
\hline \multirow{4}{*}[\mathrm{Ni}(\mathrm{HAAT})(\mathrm{OAc})_{2}(\mathrm{H}_{2}\mathrm{O})]{} & $155-390$ & 28.01 & 27.75 & $(\mathrm{OAc})_{2}+\mathrm{H}_{2} \mathrm{O}$ \\
\hline & $390-455$ & 11.68 & 11.44 & $\mathrm{C}_{3} \mathrm{H}_{6} \mathrm{~N}$ \\
\hline & $455-640$ & 45.28 & 45.56 & $\mathrm{C}_{13} \mathrm{H}_{7} \mathrm{~N}_{2} \mathrm{OS}$ \\
\hline & Residue & 15.03 & 15.24 & $\mathrm{NiO}$ \\
\hline \multirow{3}{*}[\mathrm{Zn}(\mathrm{HAAT})(\mathrm{OAc})_{2}]{} & $125-365$ & 24.87 & 24.62 & $(\mathrm{OAc})_{2}$ \\
\hline & $365-620$ & 58.29 & 58.4 & $\mathrm{C}_{16} \mathrm{H}_{13} \mathrm{~N}_{3} \mathrm{OS}$ \\
\hline & Residue & 16.84 & 16.99 & $\mathrm{ZnO}$ \\
\hline
\end{tabular}

3.6. Powder XRD Patterns. Unfortunately, several trials to get crystals of the newly synthesized metal complexes suitable for single-crystal studies did not succeed which may originate from the fact that they were soluble only in DMSO and DMF. So, the powder X-ray diffraction patterns of $\mathrm{Co}(\mathrm{II}), \mathrm{Ni}(\mathrm{II})$, and $\mathrm{Zn}$ (II) complexes were scanned in the range of 5-80 $(\theta)$ at wavelength of $1.54 \AA$ to investigate their crystallinity degree. The diffraction patterns of both $\mathrm{Co}$ (II) and $\mathrm{Ni}$ (II) complexes showed no significant peaks, and the trend of the curves decreases from maximum to minimum intensity indicating the amorphous nature of the complexes [52] (Figure S10).

On the other hand, the powder X-ray diffraction pattern of $\left[\mathrm{Zn}(\mathrm{HAAT})(\mathrm{OAc})_{2}\right]$ complex showed nine reflections at $2 \theta=6.99,11.90,15.65,17.39,20.18,22.09,24.31,31.34$, and $41.84^{\circ}$ corresponding to interplanar spacing, $d$-values, 12.63 , 7.43, 5.66, 5.10, 4.40, 4.02, 3.66, 2.85, and 2.16 (Figure 7). Powder XRD peaks were indexed into the face-centered monoclinic and $\mathrm{P} 21 / \mathrm{c}$ (14) space group with a lattice constant; $a=8.405 \pm 0.0003, b=10.183 \pm 0.0001, \quad c=13.731 \pm$ $0.0002 \AA, \alpha=90^{\circ}, \beta=104.4^{\circ}$, and $\gamma=90^{\circ}$ [53]. The calculated interplanar spacing, $\mathrm{d}$, together with relative intensities of the most intense peak was recorded and depicted in Table 5. Using the interplanar spacing $(d)$ and miller indices $(h k l)$, the lattice parameters of monoclinic (2) powder were evaluated from the peak position using the following relation $[54,55]$ :

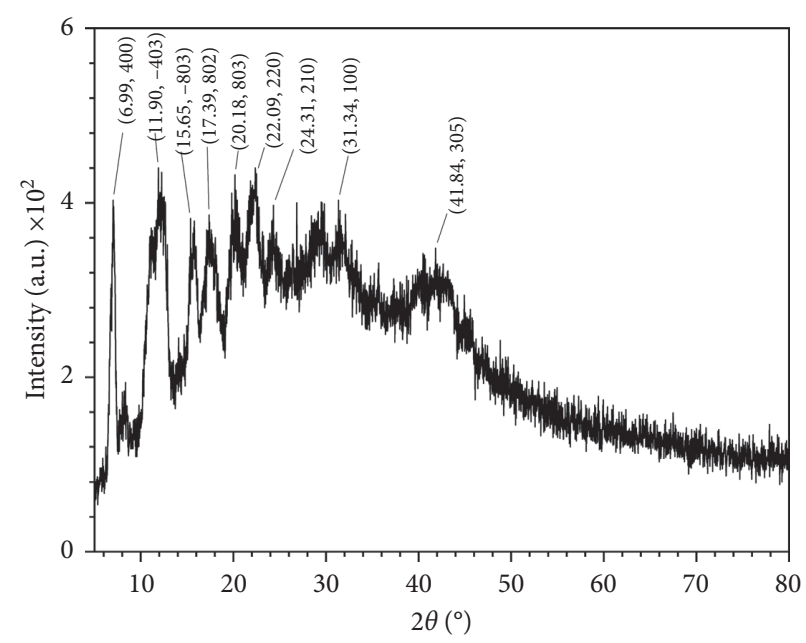

Figure 7: Powder XRD pattern of $\mathrm{Zn}(\mathrm{II})$ complex.

$$
\frac{1}{d^{2}}=\frac{1}{\sin ^{2} \beta}\left(\frac{h^{2}}{a^{2}}+\frac{k^{2} \sin ^{2} \beta}{b^{2}}+\frac{l^{2}}{c^{2}}-\frac{2 h l \cos \beta}{a c}\right) .
$$

The crystalline size of the $\mathrm{Zn}$ (II) complex, $D$, was evaluated using Debye-Scherrer's equation [56], $D=0.9$ $\lambda / \beta \cos \theta$, where $\lambda$ is the $\mathrm{X}$-ray wavelength and $\beta$ is the full width at half maximum intensity (FWHM). The obtained 
Table 5: Powder X-ray data of $\mathrm{Zn}$ (II) complex.

\begin{tabular}{|c|c|c|c|c|c|c|}
\hline $2 \theta\left(^{\circ}\right)$ & $h k l$ & $\beta\left(\right.$ FWHM) $\left(^{\circ}\right)$ & $d(\AA)$ & $D(\mathrm{~nm})$ & $\varepsilon \times 10^{-3}$ & $\delta(\mathrm{nm}) \times 10^{-3}$ \\
\hline 6.99 & 400 & 0.76 & 12.63 & 10.48 & 54.23 & 9.10 \\
\hline 11.90 & -403 & 1.91 & 7.43 & 4.19 & 79.77 & 56.95 \\
\hline 15.65 & -803 & 1.10 & 5.66 & 7.29 & 34.89 & 18.79 \\
\hline 17.39 & 802 & 1.90 & 5.10 & 4.22 & 54.31 & 56.14 \\
\hline 20.18 & 803 & 0.53 & 4.40 & 15.24 & 12.98 & 4.31 \\
\hline 22.09 & 220 & 0.96 & 4.02 & 8.46 & 21.37 & 13.96 \\
\hline 24.31 & 210 & 0.72 & 3.66 & 11.31 & 14.55 & 7.82 \\
\hline 31.34 & 100 & 0.50 & 2.85 & 16.34 & 7.85 & 3.75 \\
\hline 41.84 & 305 & 1.95 & 2.16 & 4.35 & 22.29 & 52.78 \\
\hline Average & - & 1.15 & 5.32 & 9.10 & 33.58 & 24.84 \\
\hline
\end{tabular}

crystalline size was in the range 4.19-16.34 nm exhibiting an average size of $9.10 \mathrm{~nm}$. The microstrain or lattice strain, $\varepsilon$, is a measure of the deviation from reference lattice positions and may attribute to the defects and dislocations at the grain boundaries. The lattice strain was determined from the relation, $\varepsilon=\beta / 4 \tan \theta$ [57, 58], and was found to be $33.58 \times 10^{-3}$, which denotes high lattice strain. Moreover, the dislocation density, $\delta$, which refers to the crystal imperfection, was determined from Williamson and Smallman's relation, $\delta=1 / D^{2}$ [59], and was found to be in the range from 3.76 to $56.95 \times 10^{-3} \mathrm{~nm}$ with an average value of $24.84 \times 10^{-3} \mathrm{~nm}$ which reflects the remarkable change of the grain size with values of $2 \theta$ of the complex.

3.7. Optical Band Gap. Tauc's equation was applied to estimate the optical band gap $\left(E_{g}\right)$ of the ligand and complexes from their absorption spectra, $\alpha h v=A\left(h \nu-E_{g}\right)^{r}$, where $A$ and $r$ are independent constants. The $r$ value for the indirect transition was $1 / 2$ while, for direct transition, it equals 2 $[60,61]$. The intercept with the x-axis, $h v$, in the plot of $(\alpha h \nu)^{r}$ against $(h \nu)$ at different $r$ values, established by linear portion extrapolating, represents the optical band gap $\left(E_{g}\right)$.

The plots of the ligand and complexes revealed that the transition mechanism that occurred is a direct one where at $r=2$, the straight-line was obtained (Figure 8). The data showed that the ligand has a higher $E_{g}$ value than complexes, $2.56 \mathrm{eV}$, while the $\mathrm{Ni}$ (II) complex has the lowest one, $2.18 \mathrm{eV}$ (Table 6). Therefore, it was concluded that the ligand and complexes have a semiconductive and efficient photovoltaic nature [62-66].

3.8. Molecular Modeling. The HAAT optimized structure has a planar configuration as the dihedral angles data showed, for instance, that both the carbonyl oxygen and azomethine nitrogen atoms were coplanar with each other and the moiety, $\mathrm{O}-\mathrm{C}_{\text {nph-o }}-\mathrm{C}_{\text {nph-n }}-\mathrm{N}^{1}=-0.12^{\circ}$ (Table S1). Likewise, the thiosemicarbazone moiety was planar and coplanar with acenaphthaquinone where $\mathrm{N}^{1}-\mathrm{N}^{2}-\mathrm{CS}-\mathrm{N}^{4}$ and $\mathrm{N}^{2}-\mathrm{C}_{\mathrm{S}}-\mathrm{N}^{4}$ $\mathrm{C}_{\text {allyl }}$ were 0.28 and $179.44^{\circ}$, respectively (Figure 9(a)). The ligand's bond lengths presented almost matched those obtained from single-crystal X-ray data of similar compounds [67], differences in 0.1 to $0.2 \AA$ range (Table S2). The azomethine bond angle, $\mathrm{N}^{2}-\mathrm{N}^{1}-\mathrm{C}_{\text {nph-n }}$, exhibited an ideal value for the $s p^{2}$ hybridization, $120.57^{\circ}$, while the carbonyl group suffered from small distortion from the standard value, $126.59^{\circ}$. The $s p^{3}$ hybrid NH groups showed more deviation from the standard value, $109.5^{\circ}$, where, e.g., $\mathrm{C}_{\mathrm{S}}-\mathrm{N}^{2}-\mathrm{N}^{1}$ and $\mathrm{C}_{\text {allyl }}-\mathrm{N}^{4}-\mathrm{C}_{\mathrm{S}}$ were 120.39 and $124.04^{\circ}$, respectively (Table S3).

On the other hand, the DFT optimized structure Co(II) complex revealed octahedral geometry around the metal atom in which the ligand has an angular configuration (Figure 9(b)). The dihedral angle data showed that both carbonyl oxygen and azomethine nitrogen were almost planar as $\mathrm{O}-\mathrm{C}_{\text {nph-o }}-\mathrm{C}_{\text {nph-n }}-\mathrm{N}^{1}=-8.73^{\circ}$ while the thiocarbonyl carbon, $\mathrm{C}_{s}$, and $\mathrm{N}^{2} \mathrm{H}$ nitrogen atoms were tilted on the acenaphthaquinone plane by more than $110^{\circ}$ as $\mathrm{C}_{\mathrm{S}}-\mathrm{N}^{2}-\mathrm{N}^{1}$ $\mathrm{C}_{\text {nph-n }}$ and $\mathrm{C}_{\text {nph-o }}-\mathrm{C}_{\text {nph-n }}-\mathrm{N}^{1}-\mathrm{N}^{2}$ were -112.43 and $131.97^{\circ}$, respectively. The $\mathrm{Co}(\mathrm{II})$ atom slightly deviated from the acenaphthaquinone plane where $\mathrm{C}_{\text {nph-n }}-\mathrm{C}_{\text {nph-o }}-\mathrm{O}-\mathrm{Co}$ and $\mathrm{C}_{\text {nph-o }}-\mathrm{C}_{\text {nph-n }}-\mathrm{N}^{1}$-Co angles were 19.27 and $-8.08^{\circ}$, respectively. The bond angle data cleared that the complex has a small degree of distortion as, for example, the O-Co- $\mathrm{N}^{1}$, S-Co- $\mathrm{N}^{1}$, and O-M-S were 92.30, 86.94, and $97.02^{\circ}$, respectively, which are higher or lower than the ideal value $\left(90^{\circ}\right)$. Furthermore, another type of distortion was observed from the bond length data as the Co-S, $2.24 \AA$, was longer than $\mathrm{M}-\mathrm{N}^{1}$ and $\mathrm{M}-\mathrm{O}, 1.86$ and $1.92 \AA$, respectively, but compatible with the corresponding $\mathrm{X}$-ray values $[28,67]$ (Tables S1-S3).

As $\mathrm{Co}(\mathrm{II})$ complex, the $\mathrm{Ni}(\mathrm{II})$ complex exhibited less bond angle distortion from ideal values of the octahedral structure (Figure 9(c)); e.g., O-Ni- $\mathrm{N}^{1}, \mathrm{~S}-\mathrm{Ni}-\mathrm{N}^{1}$, and O-Ni-S angles were $94.40,88.31$, and $176.93^{\circ}$, respectively. Moreover, the ligand has a less angular configuration, in comparison with the $\mathrm{Co}$ (II) complex, where the angle between the carbonyl oxygen and azomethine nitrogen, $\mathrm{O}-\mathrm{C}_{\text {nph-o }}{ }^{-}$ $\mathrm{C}_{\mathrm{nph}-\mathrm{n}}-\mathrm{N}^{1}$, was $-5.80^{\circ}$ while the thiocarbonyl carbon and $\mathrm{N}^{2} \mathrm{H}$ nitrogen atoms were tilted on the acenaphthaquinone plane as $\mathrm{C}_{\mathrm{S}}-\mathrm{N}^{2}-\mathrm{N}^{1}-\mathrm{C}_{\text {nph-n }}$ and $\mathrm{C}_{\text {nph-o }}-\mathrm{C}_{\text {nph-n }}-\mathrm{N}^{1}-\mathrm{N}^{2}$ were -158.32 and $127.30^{\circ}$, respectively. The $\mathrm{Ni}(\mathrm{II})$ atom deviated from the acenaphthaquinone plane where the $\mathrm{C}_{n p h-\mathrm{n}}-\mathrm{C}_{\text {nph-o }}$ $\mathrm{O}-\mathrm{Ni}$ and $\mathrm{C}_{\mathrm{nph}-\mathrm{o}}-\mathrm{C}_{\mathrm{nph}-\mathrm{n}^{-}}-\mathrm{N}^{1}$-Ni angles were 14.34 and $-6.51^{\circ}$, respectively. Likewise, the bond lengths exhibited another type of distortion as the Ni-S bond was longer than $\mathrm{M}-\mathrm{N}^{1}$ and $\mathrm{M}-\mathrm{O}$ bonds by $\sim 0.5 \AA$ but all were in accordance with the similar complexes reported previously $[28,67]$ (Tables S1-S3).

Moreover, in $\mathrm{Zn}(\mathrm{II})$ complex, the dihedral angles indicated that the carbonyl oxygen, azomethine nitrogen, and 


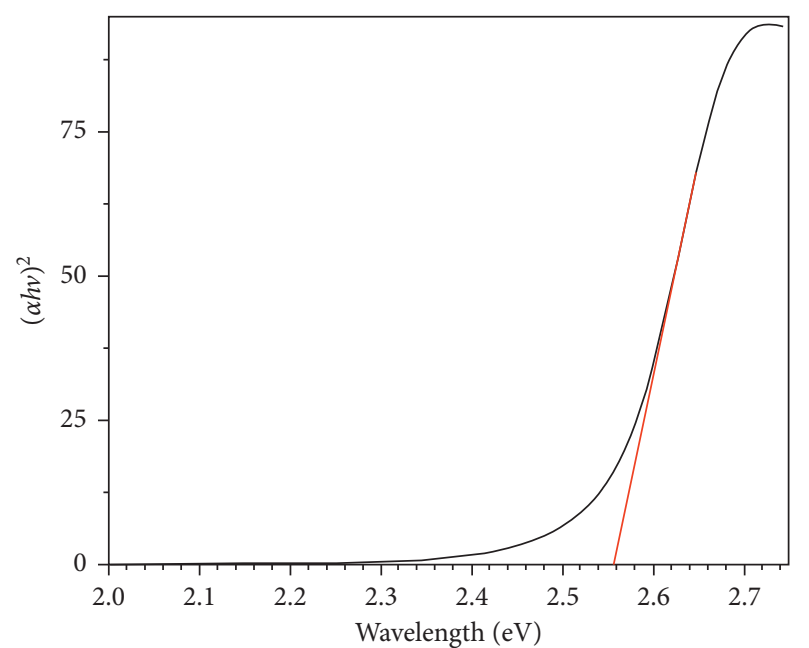

(a)

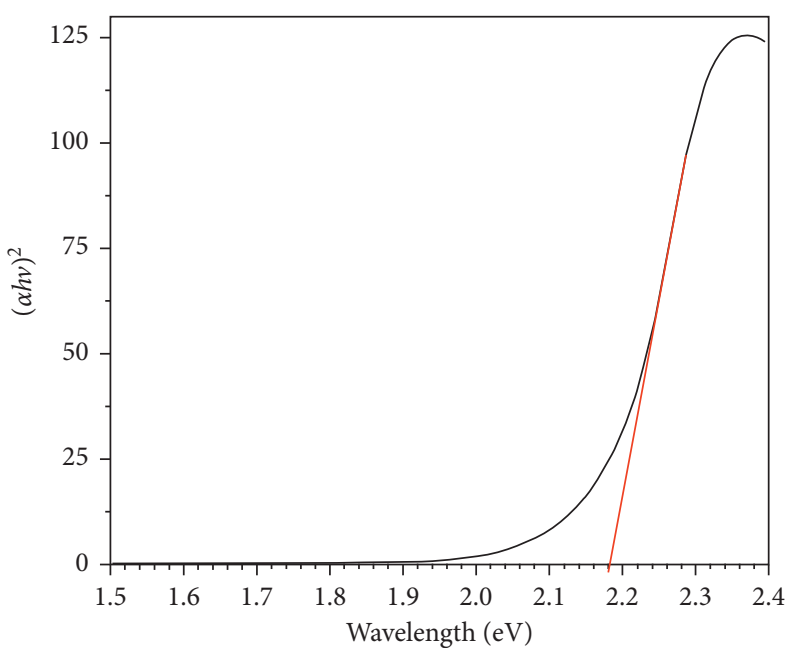

(b)

Figure 8: Tauc's plots of HAAT (a) and Ni(II) complex (b).

TABle 6: The HOMO energy $\left(\mathrm{E}_{\mathrm{H}}\right)$, LUMO energy $\left(\mathrm{E}_{\mathrm{L}}\right)$, energy gap $\left(\Delta \mathrm{E}_{\mathrm{H}-\mathrm{L}}\right)$, electronegativity $(\chi)$, global hardness $(\eta)$, softness $(\delta)$, electrophilicity $(\omega)$, and optical band gap $\left(E_{g}\right)$ of the ligand and metal complexes in $\mathrm{eV}$.

\begin{tabular}{lcccccrrr}
\hline Compound & $\mathrm{E}_{\mathrm{H}}$ & $\mathrm{E}_{\mathrm{L}}$ & $\Delta \mathrm{E}_{\mathrm{H}-\mathrm{L}}$ & $\chi$ & $\mathrm{H}$ & $\delta$ & $\omega$ & $E_{g}$ \\
\hline HAAT & -6.07 & -4.11 & 1.96 & 5.09 & 0.98 & 1.02 & 13.25 \\
Co(II) & -6.53 & -4.04 & 2.49 & 5.29 & 1.25 & 0.80 & 11.21 \\
Ni(II) & -6.15 & -4.02 & 2.13 & 5.08 & 1.06 & 0.94 & 12.15 \\
Zn(II) & -6.01 & -3.98 & 2.03 & 5.00 & 1.02 & 0.98 & 12.30 & 2.18 \\
\hline
\end{tabular}

$\mathrm{N}^{2} \mathrm{H}$ nitrogen atoms were coplanar to each other and the acenaphthaquinone moiety (Figure $9(\mathrm{~d})$ ), where $\mathrm{O}-\mathrm{C}_{\mathrm{nph}-\mathrm{o}^{-}}$ $\mathrm{C}_{\text {nph-n }}-\mathrm{N}^{1}=-0.70^{\circ}$ and $\mathrm{C}_{\text {nph-o }}-\mathrm{C}_{n p h-\mathrm{n}}-\mathrm{N}^{1}-\mathrm{N}^{2}=177.88^{\circ}$. However, the thiocarbonyl carbon atom was tilted on the plane as $\mathrm{C}_{\mathrm{S}}-\mathrm{N}^{2}-\mathrm{N}^{1}-\mathrm{C}_{\mathrm{nph}-\mathrm{n}}=154.41^{\circ}$. The $\mathrm{Zn}$ (II) atom slightly deviated from the acenaphthaquinone plane where the $\mathrm{C}_{n p h}$ ${ }_{n}-\mathrm{C}_{\text {nph-o }}-\mathrm{O}-\mathrm{Zn}$ and $\mathrm{C}_{\text {nph-o }}-\mathrm{C}_{n p h-\mathrm{n}}-\mathrm{N}^{1}-\mathrm{Zn}$ angles were 0.15 and $0.82^{\circ}$, respectively. Likewise, the $\mathrm{Zn}$ (II) complex exhibited small bond length distortion as $\mathrm{Zn}-\mathrm{N}^{1}$ was longer than $\mathrm{Zn}-\mathrm{O}$ bonds by $0.04-0.05 \AA$ and was in agreement with the X-ray reported values $[28,67]$ (Tables S1-S3).

On the other hand, the energies of the frontier molecular orbitals, HOMO and LUMO, were determined where they act as electron donor and accepter, respectively. Figure 10 displayed the 3D plots of HOMO and LUMO orbitals of the investigated compounds. As shown in Table 6, the Co(II) complex has the lowest HOMO and LUMO energies $\left(\mathrm{E}_{\mathrm{H}}\right.$ and $\mathrm{E}_{\mathrm{L}}$ ) while the $\mathrm{Zn}(\mathrm{II})$ complex exhibited the highest energies. The chemical stability and intramolecular charge transfer may be correlated with the HOMO-LUMO energy gap, $\Delta \mathrm{E}_{\mathrm{H}-\mathrm{L}}$, where the $\Delta \mathrm{E}_{\mathrm{H}-\mathrm{L}}$ decrease results in more feasible charge transfer which is one of the significant factors affecting the molecule bioactivity [68-70]. The isolated compounds presented $\Delta \mathrm{E}_{\mathrm{H}-\mathrm{L}}$ gap ranging from 1.96 to $2.49 \mathrm{eV}$ and may be ordered as $\mathrm{HAAT}>\mathrm{Zn}(\mathrm{II})>\mathrm{Ni}$ (II) $>\mathrm{Co}$ (II) (Table 6). Moreover, it was observed that the $\Delta \mathrm{E}_{\mathrm{H}-\mathrm{L}}$ gap was lower than the optical band gap $(E g)$ by only $0.05-0.60 \mathrm{eV}$.
Finally, the obtained $E_{H}$ and $E_{L}$ values were employed to determine some chemical reactivity descriptors like electronegativity $(\chi)$, global hardness $(\eta)$, softness $(\delta)$, and electrophilicity $(\omega)$ using the following equations [68] (Table 6). The data indicated that the Co(II) complex has the highest Lewis acid character and charge transfer resistance, large $\chi$, and $\eta$, respectively. The ligand has the highest electronic acceptability, softest, and electrophilicity that measure the energy reduction that originated from $\mathrm{HOMO}-$ LUMO electron flow, high $\delta$, and $\omega$, respectively.

$$
\begin{aligned}
& \chi=-\frac{1}{2}\left(E_{\text {HOMO }}+E_{L U M O}\right) \\
& \eta=-\frac{1}{2}\left(E_{\text {HOMO }}-E_{L U M O}\right) \\
& \delta=\frac{1}{\eta} \\
& \omega=\frac{\chi^{2}}{2 \eta}
\end{aligned}
$$

\subsection{Biological Application}

3.9.1. Antioxidant Activity. Antioxidants' scavenge reactive oxygen species (ROS), such as superoxide, hydroxyl, and 


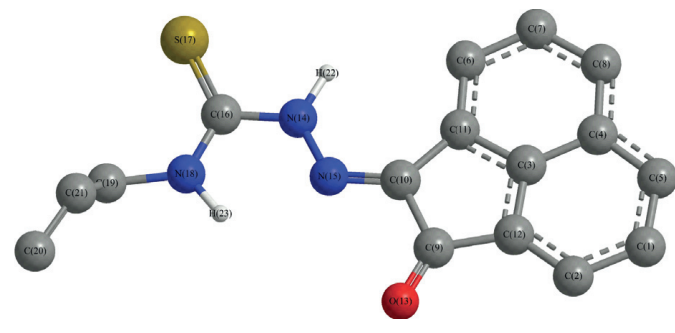

(a)

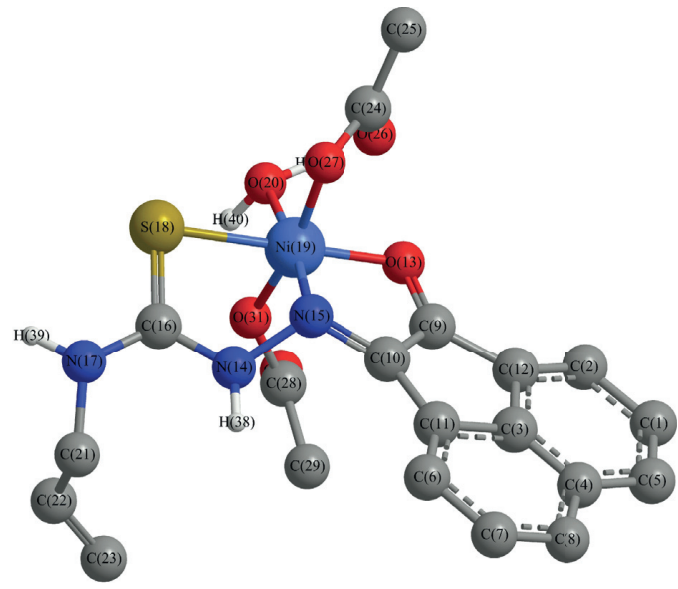

(c)

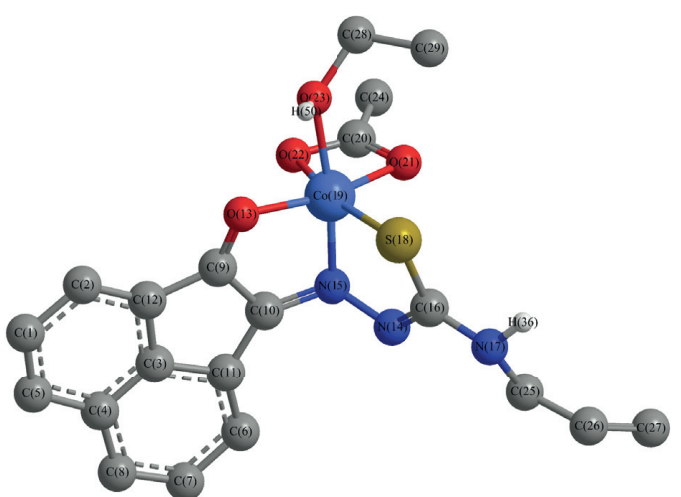

(b)

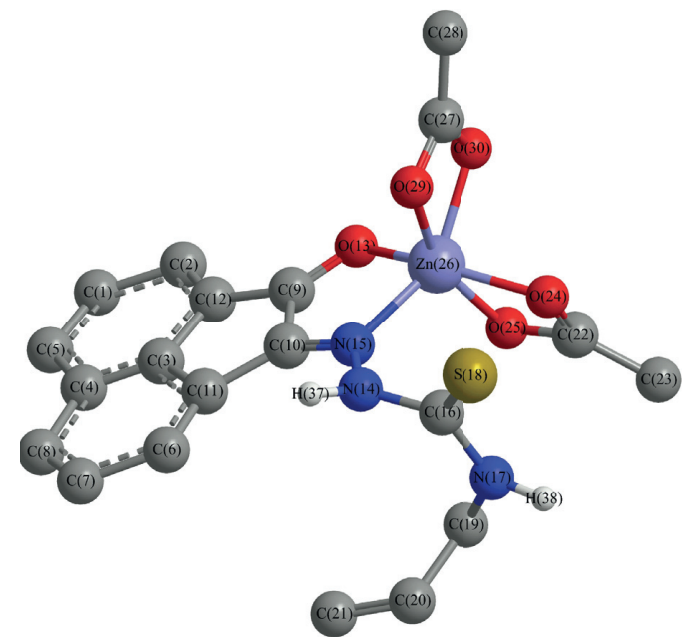

(d)

Figure 9: DFT optimized structures of HAAT (a) and $\mathrm{Co}(\mathrm{II})$ (b), $\mathrm{Ni}(\mathrm{II})$ (c), and $\mathrm{Zn}$ (II) (d) complexes.

hydrogen peroxide radicals, cause many life-threatening diseases. Human diseases, like cancer, diabetic mellitus, hypertension, and aging, may be initiated by the ROS capability to destruct DNA, proteins, and membrane functions. The ROS are a by-product of normal metabolism in different subcellular compartments, even under optimal circumstances [71-73].

The ligand and complexes were examined as antioxidant by the ABTS method in which L-ascorbic acid was used as a standard material. The data showed that the ligand and $\mathrm{Zn}$ (II) complex have high activity than other complexes and close to the ascorbic acid, 88.5 and $88.6 \%$, respectively (Table 7). The $\mathrm{Ni}(\mathrm{II})$ complex has comparable activity, $81.4 \%$, while the Co(II) complex was the lowest one, $65.3 \%$ (Figure 11). Comparison with previously reported allyl thiosemicarbazide compound, HADTsc [46], indicated that the HAAT and its complexes exhibited slightly higher antioxidant activity than HADTsc.

Finally, the L-ascorbic acid antioxidant activity may originate from its action as a reducing substance; i.e., it donates high-energy electrons to neutralize free radicals [74]. Thus, the activity of ligand may be attributed to its capability to serve as electron donors via heteroatom lone pair of electrons and its low HOMO energy. Moreover, the higher $\mathrm{Zn}$ (II) complex activity, in comparison with other complexes, may be attributed to the change in chelation environment around metal ion as all complexes have octahedral geometry but only the $\mathrm{Zn}$ (II) complex has higher electron donor ability due to the lone pair of electron of the free sulfur atom as well as lower HOMO energy.

3.9.2. In Vitro Antitumor Activity. The thiosemicarbazones and its complexes presented well-established anticancer activity $[75,76]$ which stimulated the study of HAAT and its metal complexes' cytotoxic activities against the hepatocellular carcinoma cell line (HepG2), the main type of liver cancer that is the second cause of cancer-related death [77] (Table 7). Like the antioxidant activity, both HAAT and $\mathrm{Zn}(\mathrm{II})$ complex exhibited very strong activity, $\mathrm{IC}_{50}$ $6.45 \pm 0.25$ and $6.39 \pm 0.18 \mu \mathrm{M}$, respectively, comparable to the doxorubicin standard, $4.50 \pm 0.2 \mu \mathrm{M}$. The Ni(II) complex has moderate activity, $\mathrm{IC}_{50} 21.46 \pm 0.72$, while the Co(II) complex has weak cytotoxic activity, weak activity $67.31 \pm 1.35 \mu \mathrm{M}$ (Figure 11). In comparison with the data of allyl thiosemicarbazide compound, HADTsc [46] earlier reported, it was clear that the HAAT and its complexes displayed higher cytotoxic activity than HADTsc. Moreover, 
HOMO

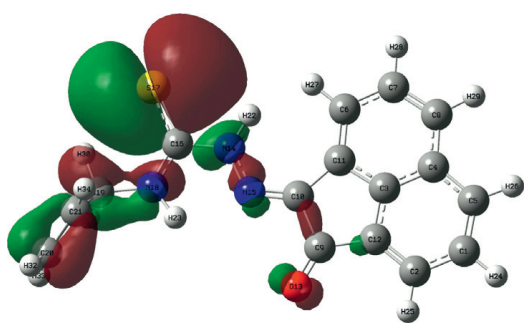

LUMO

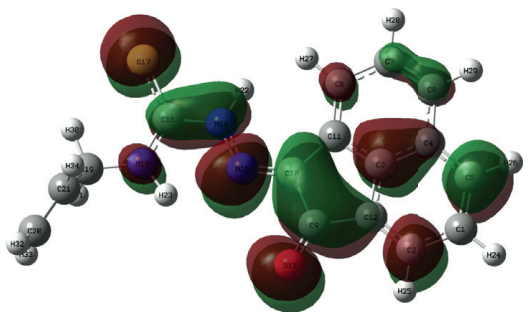

HAAT
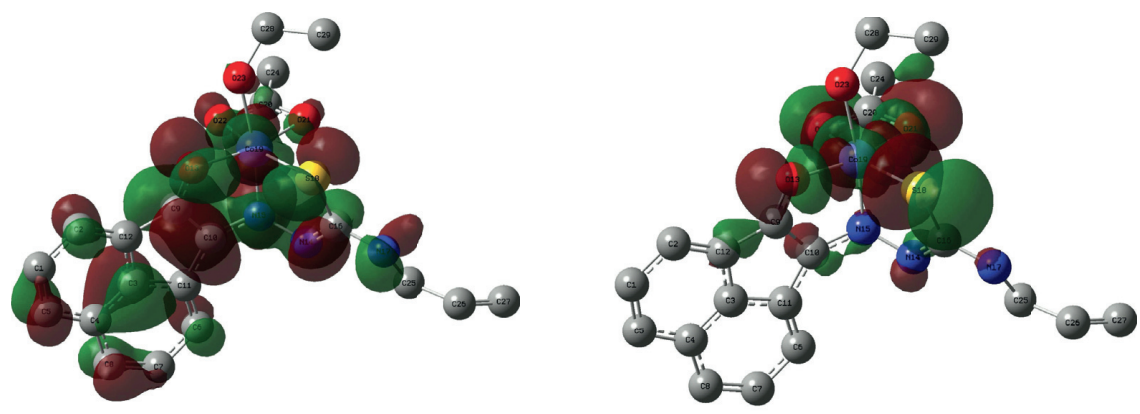

$\mathrm{Co}(\mathrm{II})$
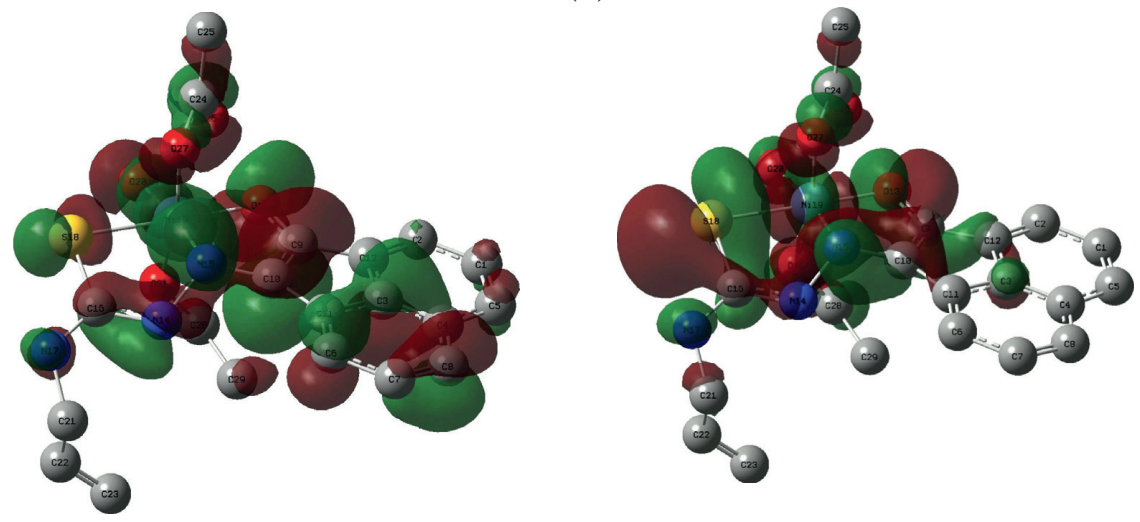

$\mathrm{Ni}(\mathrm{II})$
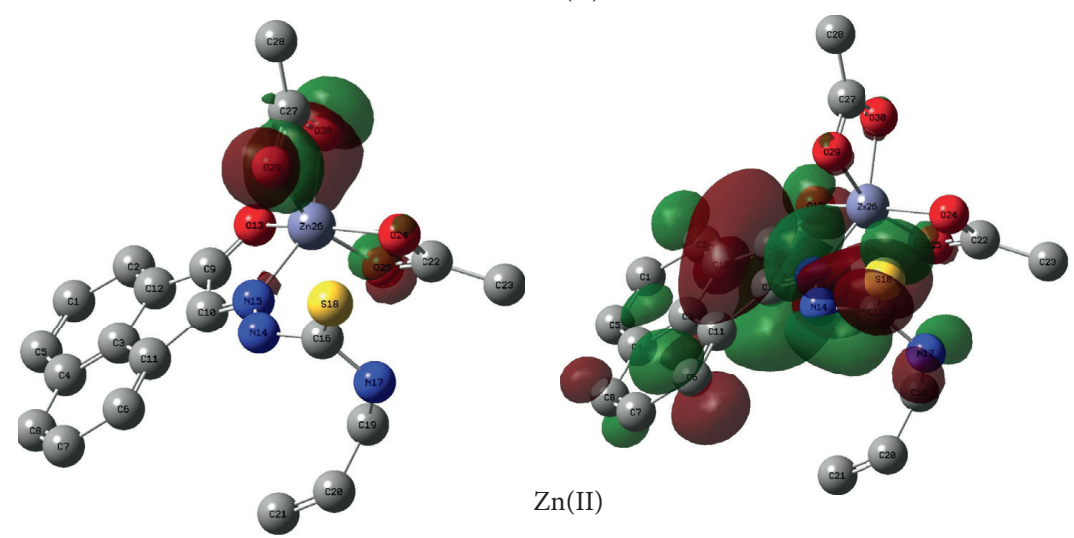

Figure 10: The 3D plots of the investigated compound HOMO and LUMO orbitals.

the average cells' relative viability percent at different concentrations of examined compounds indicated that ligand has a higher potent effect than the complexes at different concentrations while the $\mathrm{Zn}$ (II) complex was the most active complex (Figure 12). The selectivity index (SI) was calculated as the average of the $\mathrm{IC}_{50}$ value in the normal cell line divided by the $\mathrm{IC}_{50}$ value in the cancer cell line obtained, where the SI $>2$ indicates high selectivity [78] (Table 7). Although both HAAT and $\mathrm{Zn}$ (II) complex exhibited very strong activity, their SI was 1.14 and 1.28, respectively, which 
TABLE 7: ABTS antioxidant assay and in vitro cytotoxicity against HepG2 cell line of the ligand and its complexes.

\begin{tabular}{lccr}
\hline ABTS assay & & \multicolumn{2}{c}{ In vitro cytotoxicity HePG2 } \\
Compounds & Inhibition $\%$ & Compounds & IC $_{50}(\mu \mathrm{M})^{*}$ \\
\hline L-Ascorbic acid & 88.8 & Doxorubicin & $4.50 \pm 0.2$ \\
HAAT & 88.4 & HAAT & $6.45 \pm 0.25$ \\
Co(II) complex & 65.3 & Co(II) complex & $67.31 \pm 1.35$ \\
Ni(II) complex & 81.4 & Ni(II) complex & $21.46 \pm 0.72$ \\
Zn(II) complex & 88.6 & Zn(II) complex & $6.39 \pm 0.18$ \\
\hline
\end{tabular}

${ }^{*} \mathrm{IC}_{50}$ : 1-10 (very strong), 11-20 (strong), 21-50 (moderate), 51-100 (weak), and above 100 (noncytotoxic).

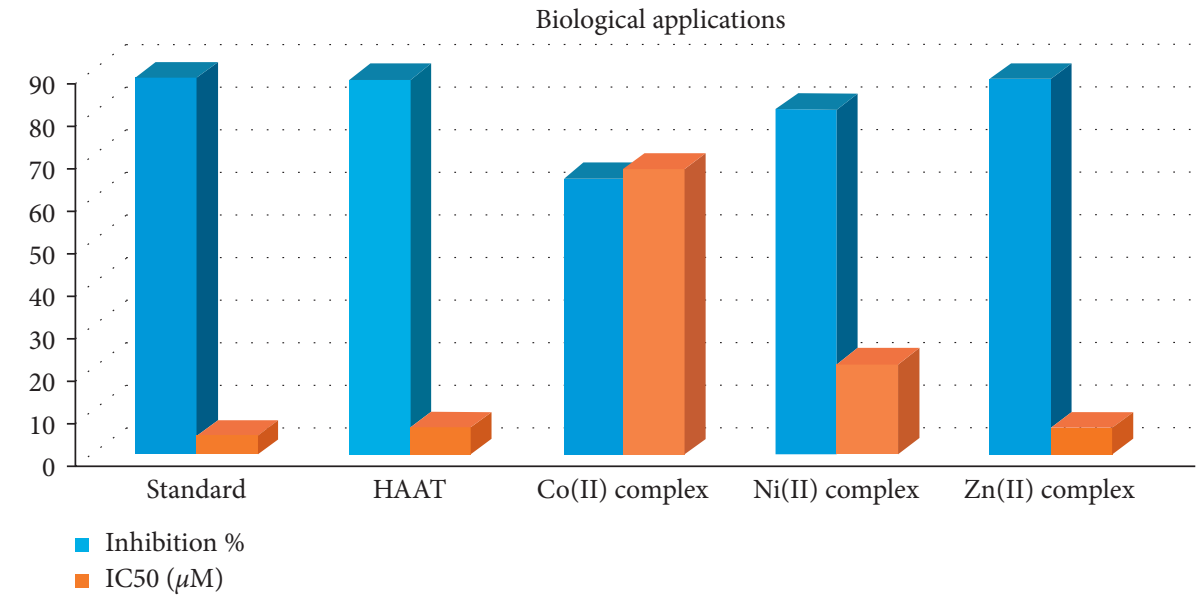

Figure 11: Antioxidant (Inhibition \%) and antitumor (IC50) activities of HAAT and its complexes.

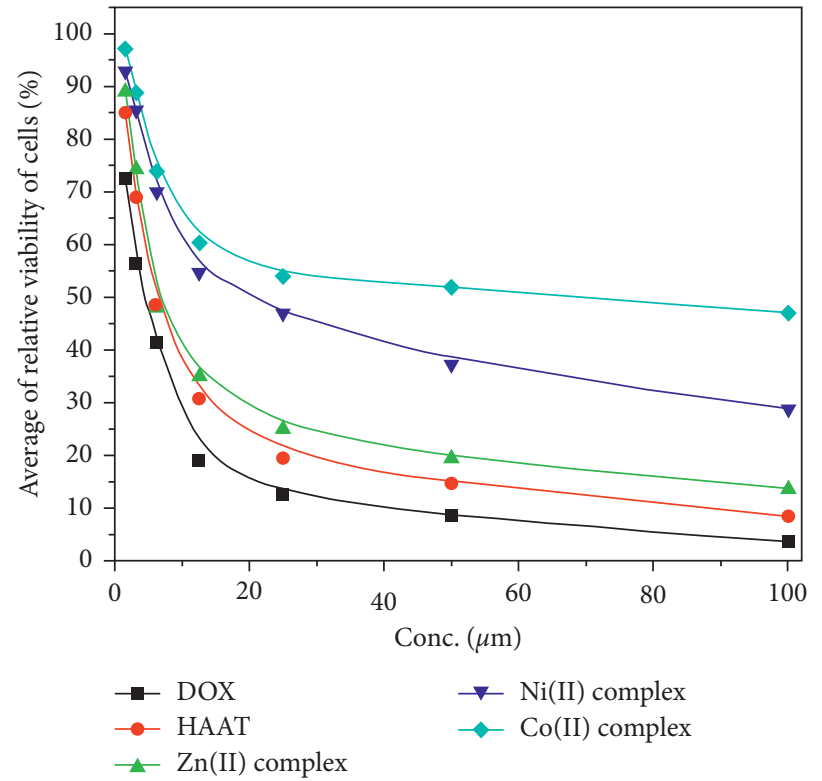

FIGURE 12: In vitro cytotoxic activities of HAAT and its complexes compared with the standard doxorubicin against HepG2cell line.

indicated that they processed low selectivity toward the cancer cells. Also, the $\mathrm{Co}$ (II) and $\mathrm{Ni}$ (II) complexes exhibited lower SI in accordance with their high $\mathrm{IC}_{50}$ values.

Finally, the biological activity of metal complexes mainly depends on the coordination sphere around the central metal ion. According to Tweedy's chelation theory, the chelation process leads to a reduction of the metal atom polarity through partial sharing of its positive charge with donor groups and possible electron delocalization over the entire molecule which results in increasing the lipophilic character of the complex. Thus, chelation enhances the penetration of the complexes through the cell membrane 
and the deactivation of various cellular enzymes metalbinding sites in addition to denaturation of cellular proteins causing the normal cellular processes to be impaired [79-81]. Hence, from the structure point of view, the $\mathrm{Zn}$ (II) complex has an octahedral geometry, like other complexes, in which the ligand chelated via the carbonyl oxygen and azomethine nitrogen atoms while the sulfur atom is free in addition to two bidentate acetate ions. Therefore, its activity may originate from (i) higher permeability through the cell membrane as it has more lipophilic character and (ii) the capability to form hydrogen bonds via the free sulfur atom with the active centers of different cellular constituents resulting in interference with normal cellular processes [79-81].

\section{Conclusion}

The spectral characterization of the new Schiff's base derivative, HAAT, N-allyl-2-(2-oxoacenaphthylen-1(2H)-ylidene)hydrazine-1-carbothioamide, revealed that it is in thione form. The HAAT formed 1:1 (M:L) octahedral complexes with $\mathrm{Co}(\mathrm{II}), \mathrm{Ni}(\mathrm{II})$, and $\mathrm{Zn}(\mathrm{II})$ acetates. The ligand chelated with $\mathrm{Co}(\mathrm{II}), \mathrm{Ni}(\mathrm{II})$, and $\mathrm{Zn}$ (II) ions as ONS donor in mononegative and neutral tridentate in $\mathrm{Co}$ (II) and $\mathrm{Ni}$ (II) complexes, respectively, while in $\mathrm{Zn}$ (II) complex, it acts as neutral bidentate, via ON atoms. The DFT calculations showed that the ligand has a planar structure while it has bent conformation reflecting its flexibility. The antioxidant activity investigation revealed that the ligand and $\mathrm{Zn}$ (II) complex have high activity almost equal to the standard material, ascorbic acid. Similarly, the MTT assay was utilized for the examination of the antitumor activity using the hepatocellular carcinoma cell line (HepG2). The data revealed that the ligand and $\mathrm{Zn}$ (II) complex presented very strong activity.

\section{Data Availability}

The data that support the findings of this study are available in the supplementary material of this article.

\section{Conflicts of Interest}

The authors declare that they have no conflicts of interest.

\section{Acknowledgments}

The authors extend their appreciation to the Deanship of Scientific Research at King Khalid University for funding this work through the research groups program under Grant Number R.G.P.1/236/41.

\section{Supplementary Materials}

Figure S1: IR spectrum of HAAT in comparison with acenaphthaquinone. Figure S2: IR spectrum of $\mathrm{Co}$ (II) complex. Figure S3: IR spectrum of $\mathrm{Ni}(\mathrm{II})$ complex. Figure S4: The mass spectrum of the $\mathrm{Co}$ (II) complex. Figure S5: The mass spectrum of the $\mathrm{Ni}(\mathrm{II})$ complex. Figure S6: The mass spectrum of the $\mathrm{Zn}(\mathrm{II})$ complex. Figure S7: Electronic spectra of HAAT (a) and Co(II) complex (b). Figure S8: The TG curve of HAAT. Figure S9: The TG curve of $\mathrm{Ni}(\mathrm{II})$ complex. Figure S10: The powder XRD pattern of the $\mathrm{Co}$ (II) and $\mathrm{Ni}(\mathrm{II})$ complexes. Table S1: DFT calculated dihedral angles of the ligand and metal complexes $\left(^{\circ}\right)$. Table S2: DFT calculated bond length of the ligand and metal complexes

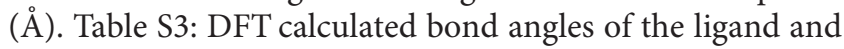
metal complexes $\left({ }^{\circ}\right)$. (Supplementary Materials)

\section{References}

[1] W. Al Zoubi, A. A. S. Al-Hamdani, and M. Kaseem, "Synthesis and antioxidant activities of Schiff bases and their complexes: a review," Applied Organometallic Chemistry, vol. 30, no. 10, pp. 810-817, 2016.

[2] M. Zahedifard, F. L. Faraj, M. Paydar et al., "Synthesis, characterization and apoptotic activity of quinazolinone Schiff base derivatives toward MCF-7 cells via intrinsic and extrinsic apoptosis pathways," Scientific Reports, vol. 5, p. 11544, 2015.

[3] L. Li, Z. Li, K. Wang et al., "Design, synthesis, and biological activities of aromatic gossypol Schiff base derivatives," Journal of Agricultural and Food Chemistry, vol. 62, no. 46, pp. 11080-11088, 2014.

[4] J.-C. Qin, X.-Y. Cheng, K.-C. Yu, R. Fang, M.-F. Wang, and Z.-Y. Yang, "Design of a novel Schiff-base fluorescent sensor for Al3+: experimental and computational studies," Analytical Methods, vol. 7, no. 16, pp. 6799-6803, 2015.

[5] J. Kumar, M. J. Sarma, P. Phukan, and D. K. Das, "A new simple Schiff base fluorescence "on" sensor for $\mathrm{Al}^{3+}$ and its living cell imaging," Dalton Transactions, vol. 44, no. 10, pp. 4576-4581, 2015.

[6] D. Daoud, T. Douadi, S. Issaadi, and S. Chafaa, "Adsorption and corrosion inhibition of new synthesized thiophene Schiff base on mild steel $\mathrm{X}_{52}$ in $\mathrm{HCl}$ and $\mathrm{H}_{2} \mathrm{SO}_{4}$ solutions," Corrosion Science, vol. 79, pp. 50-58, 2014.

[7] N. Dharmaraj, P. Viswanathamurthi, and K. Natarajan, "Ruthenium (II) complexes containing bidentate Schiff bases and their antifungal activity," Transition Metal Chemistry, vol. 26, no. 1-2, pp. 105-109, 2001.

[8] J. R. Dimmock, R. N. Puthucode, J. M. Smith et al., "(Aryloxy) aryl semicarbazones and related compounds: a novel class of anticonvulsant agents possessing high activity in the maximal electroshock screen," Journal of Medicinal Chemistry, vol. 39, no. 20, pp. 3984-3997, 1996.

[9] T. S. Lobana, R. Sharma, G. Bawa, and S. Khanna, "Bonding and structure trends of thiosemicarbazone derivatives of metals: an overview," Coordination Chemistry Reviews, vol. 253, no. 7-8, pp. 977-1055, 2009.

[10] S. Dutta, F. Basuli, A. Castineiras, S.-M. Peng, G.-H. Lee, and S. Bhattacharya, "Variable coordination modes of benzaldehyde thiosemicarbazones - synthesis, structure, and electrochemical properties of some ruthenium complexes," European Journal of Inorganic Chemistry, vol. 2008, no. 29, pp. 4538-4546, 2008.

[11] M. Milenković, A. Pevec, I. Turel et al., "Synthesis, characterization, DFT calculation and biological activity of squareplanar $\mathrm{Ni}(\mathrm{II})$ complexes with tridentate PNO ligands and monodentate pseudohalides. Part II," European Journal of Medicinal Chemistry, vol. 87, pp. 284-297, 2014.

[12] N. Özdemir, M. Şahin, T. Bal-Demirci, and B. Ülküseven, "The asymmetric ONNO complexes of dioxouranium(VI) with N1,N4-diarylidene-S-propyl-thiosemicarbazones 
derived from 3,5-dichlorosalicylaldehyde: synthesis, spectroscopic and structural studies," Polyhedron, vol. 30, no. 3, pp. 515-521, 2011.

[13] C. Zhao, X. Chen, D. Zang et al., "Platinum-containing compound platinum pyrithione is stronger and safer than cisplatin in cancer therapy," Biochemical Pharmacology, vol. 116, pp. 22-38, 2016.

[14] T. Bal-Demirci, M. Şahin, E. Kondakçı, M. Özyürek, B. Ülküseven, and R. Apak, "Synthesis and antioxidant activities of transition metal complexes based 3-hydroxysalicylaldehyde-S-methylthiosemicarbazone," Spectrochimica Acta Part A: Molecular and Biomolecular Spectroscopy, vol. 138, pp. 866-872, 2015.

[15] M. M. Subarkhan, R. Prabhu, R. R. Kumar, and R. Ramesh, "Antiproliferative activity of cationic and neutral thiosemicarbazone copper (II) complexes," RSC Advances, vol. 6, no. 30, pp. 25082-25093, 2016.

[16] K. Y. Salim, S. Maleki Vareki, W. R. Danter, S. San-Marina, and J. Koropatnick, "COTI-2, a novel small molecule that is active against multiple human cancer cell lines in vitro and In vivo," Oncotarget, vol. 7, no. 27, pp. 41363-41379, 2016.

[17] A. Lindemann, A. A. Patel, N. L. Silver et al., "COTI-2, A novel thiosemicarbazone derivative, exhibits antitumor activity in HNSCC through p53-dependent and -independent mechanisms," Clinical Cancer Research: An Official Journal of the American Association for Cancer Research, vol. 25, no. 18, pp. 5650-5662, 2019.

[18] L. C. Dias, G. M. de Lima, C. B. Pinheiro, M. A. C. Nascimento, and R. S. Bitzer, "Molecular and supramolecular properties of nitroaromatic thiosemicarbazones: synthesis, spectroscopy, X-ray structure elucidation and DFT calculations," Journal of Molecular Structure, vol. 1131, pp. 79-86, 2017.

[19] D. Kovala-Demertzi, M. A. Demertzis, E. Filiou et al., "Platinum (II) and palladium (II) complexes with 2-acetyl pyridine $4 \mathrm{~N}$-ethyl thiosemicarbazone able to overcome the cis-platin resistance. Structure, antibacterial activity and DNA strand breakage," Biometals, vol. 16, no. 3, pp. 411-418, 2003.

[20] D. Kovala-Demertzi, A. Domopoulou, M. A. Demertzis, A. Papageorgiou, and D. X. West, "Palladium(II) complexes of 2-acetylpyridine N(4)-propyl, N(4)-dipropyl- and 3-hexamethyleneiminylthiosemicarbazones with potentially interesting biological activity. Synthesis, spectral properties, antifungal and in vitro antitumor activity," Polyhedron, vol. 16, no. 20, pp. 3625-3633, 1997.

[21] I. Yavari and A. Khajeh-Khezri, "Recent advances in the synthesis of hetero- and carbocyclic Compounds- and complexes based on acenaphthylene-1,2-dione," Synthesis, vol. 50, no. 20, pp. 3947-3973, 2018.

[22] G. M. Ziarani, P. Hajiabbasi, and P. Gholamzadeh, "Development of the acenaphthenequinone reactions," Heterocycles: An International Journal for Reviews and Communications in Heterocyclic Chemistry, vol. 85, no. 8, pp. 1869-1890, 2012.

[23] C. Lodeiro, J. L. Capelo, J. C. Mejuto et al., "Light and colour as analytical detection tools: a journey into the periodic table using polyamines to bio-inspired systems as chemosensors," Chemical Society Reviews, vol. 39, no. 8, pp. 2948-2976, 2010.

[24] M. C. Rodriguez-Argüelles, M. B. Ferrari, G. G. Fava et al., "Acenaphthenequinone thiosemicarbazone and its transition metal complexes: synthesis, structure, and biological activity," Journal of Inorganic Biochemistry, vol. 66, no. 1, pp. 7-17, 1997.

[25] J. L. Hyatt, R. M. Wadkins, L. Tsurkan et al., "Planarity and constraint of the carbonyl groups in 1,2-diones are determinants for selective inhibition of human carboxylesterase 1," Journal of Medicinal Chemistry, vol. 50, no. 23, pp. 5727-5734, 2007.

[26] Z. Zhang, H. Yang, G. Wu, Z. Li, T. Song, and X. Q. Li, "Probing the difference between $\mathrm{BH} 3$ groove of $\mathrm{Mcl}-1$ and Bcl-2 protein: implications for dual inhibitors design," European Journal of Medicinal Chemistry, vol. 46, no. 9, pp. 3909-3916, 2011.

[27] I. M. Kenawy, M. M. Hassanien, M. H. Abdel-Rhman, R. R. Zaki, and H. S. Rashed, "Synthesis and characterization of $\mathrm{Hg}(\mathrm{II})$ and $\mathrm{Cd}(\mathrm{II})$ complexes derived from the novel acenaphthaquinone-4-phenyl thiosemicarbazone and its CPE application," Egyptian Journal of Basic and Applied Sciences, vol. 3, no. 1, pp. 106-117, 2016.

[28] S. Kumar, A. Hansda, A. Chandra et al., "Co(II), Ni(II), Cu(II) and $\mathrm{Zn}(\mathrm{II})$ complexes of acenaphthoquinone 3-(4-benzylpiperidyl)thiosemicarbazone: synthesis, structural, electrochemical and antibacterial studies," Polyhedron, vol. 134, pp. 11-21, 2017.

[29] N. Abdolhi, M. Aghaei, A. Soltani et al., "Synthesis and antibacterial activities of novel $\mathrm{Hg}$ (II) and $\mathrm{Zn}$ (II) complexes of bis(thiosemicarbazone) acenaphthenequinone loaded to MWCNTs," Journal of Structural Chemistry, vol. 60, no. 5, pp. 845-853, 2019.

[30] S. I. Pascu, P. A. Waghorn, T. D. Conry et al., "Designing $\mathrm{Zn}$ (ii) and $\mathrm{Cu}$ (ii) derivatives as probes for in vitro fluorescence imaging," Dalton Transactions, vol. 43, no. 43, pp. 4988-4997, 2007.

[31] G. Jeffery, J. Bassett, J. Mendham, and R. Denney, Vogel's Quantitative Chemical Analysis, Longman Scientific \& Technical Longman Group UK Limited, Essex CM20 2JE, England, 5th edition, 1989.

[32] M. Frisch, G. Trucks, H. Schlegel et al., Gaussian 09, Revision A. 1, Gaussian, Wallingford, CT, USA, 2009.

[33] A. D. Becke, "Density-functional thermochemistry. III. The role of exact exchange," The Journal of Chemical Physics, vol. 98, no. 7, pp. 5648-5652, 1993.

[34] C. Lee, W. Yang, and R. G. Parr, "Development of the ColleSalvetti correlation-energy formula into a functional of the electron density," Physical Review B, vol. 37, no. 2, pp. 785-789, 1988.

[35] J. P. Perdew and Y. Wang, "Pair-distribution function and its coupling-constant average for the spin-polarized electron gas," Physical Review B, vol. 46, no. 20, pp. 12947-12954, 1992.

[36] R. Dennington, T. Keith, and J. Millam, GaussView, Version 5, Semichem Inc., Shawnee Mission, KS, USA, 2009.

[37] E. A. Lissi, B. Modak, R. Torres, J. Escobar, and A. Urzua, "Total antioxidant potential of resinous exudates fromHeliotropiumspecies, and a comparison of the ABTS and DPPH methods," Free Radical Research, vol. 30, no. 6, pp. 471-477, 1999.

[38] R. Aeschbach, J. Löliger, B. C. Scott et al., “Antioxidant actions of thymol, carvacrol, 6-gingerol, zingerone and hydroxytyrosol," Food and Chemical Toxicology, vol. 32, no. 1, pp. 31-36, 1994.

[39] T. Mosmann, "Rapid colorimetric assay for cellular growth and survival: application to proliferation and cytotoxicity assays," Journal of Immunological Methods, vol. 65, no. 1-2, pp. 55-63, 1983.

[40] F. Denizot and R. Lang, "Rapid colorimetric assay for cell growth and survival," Journal of Immunological Methods, vol. 89, no. 2, pp. 271-277, 1986.

[41] W. J. Geary, "The use of conductivity measurements in organic solvents for the characterisation of coordination 
compounds," Coordination Chemistry Reviews, vol. 7, no. 1, pp. 81-122, 1971.

[42] M. M. Hassanien, I. M. Gabr, M. H. Abdel-Rhman, and A. A. El-Asmy, "Synthesis and structural investigation of mono-and polynuclear copper complexes of 4-ethyl-1-(pyridin-2-yl) thiosemicarbazide," Spectrochimica Acta Part A: Molecular and Biomolecular Spectroscopy, vol. 71, no. 1, pp. 73-79, 2008.

[43] M. I. Orif and M. H. Abdel-Rhman, "Synthesis, spectral and structural studies on some new isonicotinic thiosemicarbazide complexes and its biological activity," Polyhedron, vol. 98, pp. 162-179, 2015.

[44] R. Silverstein, F. Webster, and D. Kiemle, Spectrometric Identification of Organic Compounds, John Wiley \& Sons, Hoboken, NJ, USA, 7th edition, 2006.

[45] K. Nakamoto, Infrared and Raman Spectra of Inorganic and Coordination Compounds, John Wiley \& Sons Inc., Hoboken, NY, USA, 6th ed. edition, 2009.

[46] K. Abou-Melha, "Spectral, modeling and anticancer activity studies on the newly synthesized N-allyl-2-(2, 4-dinitrophenyl) hydrazine-1-carbothioamide and some bivalent metal complexes," Journal of Molecular Structure, vol. 1223, p. 128949, 2020.

[47] A. D. Ahmed and N. R. Chaudhuri, "Acid hydrazides as ligands-II: metal complexes of dicarboxylic acid (di) hydrazides," Journal of Inorganic and Nuclear Chemistry, vol. 31, no. 8, pp. 2545-2556, 1969.

[48] M. H. Abdel-Rhman, M. A. Hussien, H. M. Mahmoud, and N. M. Hosny, "Synthesis, characterization, molecular docking and cytotoxicity studies on N-benzyl-2-isonicotinoylhydrazine-1-carbothioamide and its metal complexes," Journal of Molecular Structure, vol. 1196, pp. 417-428, 2019.

[49] N. M. Hosny, N. Y. Hassan, H. M. Mahmoud, and M. H. Abdel-Rhman, "Synthesis, characterization and cytotoxicity of new 2-isonicotinoyl-N-phenylhydrazine-1-carbothioamide and its metal complexes," Applied Organometallic Chemistry, vol. 33, no. 8, 2019.

[50] A. B. P. Lever, Inorganic Electronic Spectroscopy, Elsevier Publishing Company, Amsterdam, Netherlands, 1st edition, 1968.

[51] N. M. Hosny, M. A. Hussien, R. Motawa, A. Belal, and M. H. Abdel-Rhman, "Synthesis, Spectral, Modeling, Docking and Cytotoxicity Studies on 2-(2-aminobenzoyl)-N-ethylhydrazine-1-carbothioamide and its divalent metal complexes," Applied Organometallic Chemistry, vol. 34, no. 11, 2020.

[52] G. Y. Nagesh and B. H. M. Mruthyunjayaswamy, "Synthesis, characterization and biological relevance of some metal (II) complexes with oxygen, nitrogen and oxygen (ONO) donor Schiff base ligand derived from thiazole and 2-hydroxy-1naphthaldehyde," Journal of Molecular Structure, vol. 1085, pp. 198-206, 2015.

[53] B. L. Barnett, H. C. Kretschmar, and F. A. Hartman, "Structural characterization of bis(N-oxopyridine-2-thionato) zinc(II)," Inorganic Chemistry, vol. 16, no. 8, pp. 1834-1838, 1977.

[54] V. Mote, Y. Purushotham, and B. Dole, "Williamson-Hall analysis in estimation of lattice strain in nanometer-sized $\mathrm{ZnO}$ particles," Journal of Theoretical and Applied Physics, vol. 6, no. 1, p. 6, 2012.

[55] M. T. Kesim and C. Durucan, "Indium tin oxide thin films elaborated by sol-gel routes: the effect of oxalic acid addition on optoelectronic properties," Thin Solid Films, vol. 545, pp. 56-63, 2013.

[56] F. Haque, N. K. Elumalai, M. Wright et al., "Annealing induced microstructure engineering of antimony tri-selenide thin films," Materials Research Bulletin, vol. 99, pp. 232-238, 2018.

[57] K. Rahman, F. Haque, N. Khan et al., "Effect of $\mathrm{CdCl} 2$ treatment on thermally evaporated CdTe thin films," Chalcogenide Letters, vol. 11, no. 3, pp. 129-139, 2014.

[58] P. Chelvanathan, Y. Yusoff, F. Haque et al., "Growth and characterization of RF-sputtered $\mathrm{ZnS}$ thin film deposited at various substrate temperatures for photovoltaic application," Applied Surface Science, vol. 334, pp. 138-144, 2015.

[59] M. A. Mahmud, N. K. Elumalai, M. B. Upama et al., "Controlled nucleation assisted restricted volume solvent annealing for stable perovskite solar cells," Solar Energy Materials and Solar Cells, vol. 167, pp. 70-86, 2017.

[60] J. Tauc, R. Grigorovici, and A. Vancu, "Optical properties and electronic structure of amorphous germanium," Physica Status Solidi (B), vol. 15, no. 2, pp. 627-637, 1966.

[61] R. Pandey, S. Sahu, and S. Chandra, Handbook of Semiconductor Electrodeposition, Marcel Dekker, New York, NY, USA, Inc1996.

[62] M.-L. Fu, G.-C. Guo, X. Liu, B. Liu, L.-Z. Cai, and J.-S. Huang, "Syntheses, structures and properties of three selenoarsenates templated by transition metal complexes," Inorganic Chemistry Communications, vol. 8, no. 1, pp. 18-21, 2005.

[63] N. M. Hosny, "Single crystalline $\mathrm{Co}_{3} \mathrm{O}_{4}$ : synthesis and optical properties," Materials Chemistry and Physics, vol. 144, no. 3, pp. 247-251, 2014.

[64] N. M. Hosny, "Synthesis, characterization and optical band gap of $\mathrm{NiO}$ nanoparticles derived from anthranilic acid precursors via a thermal decomposition route," Polyhedron, vol. 30, no. 3, pp. 470-476, 2011.

[65] N. M. Hosny and A. Dahshan, "Facile synthesis and optical band gap calculation of $\mathrm{Mn}_{3} \mathrm{O}_{4}$ nanoparticles," Materials Chemistry and Physics, vol. 137, no. 2, pp. 637-643, 2012.

[66] N. M. Hosny and A. Dahshan, "Synthesis, structure and optical properties of $\mathrm{SnS}_{2}, \mathrm{CdS}$ and $\mathrm{HgS}$ nanoparticles from thioacetate precursor," Journal of Molecular Structure, vol. 1085, pp. 78-83, 2015.

[67] C.-Z. Zhang, Y.-X. Su, and M.-X. Niu, "A selective chemosensor for detection of $\mathrm{Ag}(\mathrm{I})$ and $\mathrm{Cu}(\mathrm{I})$ based on an acenaphthoquinone derivative and its complexes," Journal of Coordination Chemistry, vol. 69, no. 21, pp. 3158-3171, 2016.

[68] S. Xavier, S. Periandy, and S. Ramalingam, "NBO, conformational, NLO, HOMO-LUMO, NMR and electronic spectral study on 1-phenyl-1-propanol by quantum computational methods," Spectrochimica Acta Part A: Molecular and Biomolecular Spectroscopy, vol. 137, pp. 306-320, 2015.

[69] M. M. Makhlouf, A. S. Radwan, and B. Ghazal, "Experimental and DFT insights into molecular structure and optical properties of new chalcones as promising photosensitizers towards solar cell applications," Applied Surface Science, vol. 452, pp. 337-351, 2018.

[70] A. Bouchoucha, S. Zaater, S. Bouacida, H. Merazig, and S. Djabbar, "Synthesis and characterization of new complexes of nickel (II), palladium (II) and platinum(II) with derived sulfonamide ligand: structure, DFT study, antibacterial and cytotoxicity activities," Journal of Molecular Structure, vol. 1161, pp. 345-355, 2018.

[71] M. B. Ferrari, F. Bisceglie, G. G. Fava et al., "Synthesis, characterization and biological activity of two new polymeric copper (II) complexes with $\alpha$-ketoglutaric acid 
thiosemicarbazone," Journal of Inorganic Biochemistry, vol. 89, no. 1, pp. 36-44, 2002.

[72] A. Shrivastav, N. K. Singh, P. Tripathi, T. George, J. R. Dimmock, and R. K. Sharma, "Copper(II) and manganese(III) complexes of $\mathrm{N}^{\prime}$-[(2-hydroxy phenyl) carbonothioyl] pyridine-2-carbohydrazide: novel therapeutic agents for cancer," Biochimie, vol. 88, no. 9, pp. 1209-1216, 2006.

[73] D. Meriane, G. Genta-Jouve, M. Kaabeche, S. Michel, and S. Boutefnouchet, "Rapid identification of antioxidant compounds of Genista saharae coss. \& dur. By combination of DPPH scavenging assay and HPTLC-MS," Molecules, vol. 19, no. 4, pp. 4369-4379, 2014.

[74] F. E. Pehlivan, "Vitamin C: an antioxidant agent," in Vitamin C, pp. 23-35, IntechOpen, London, UK, 2017.

[75] N. Rajendran, A. Periyasamy, N. Kamatchi, and V. Solomon, "Biological evaluation of copper(II) complexes on N(4)substituted thiosemicarbazide derivatives and diimine co-ligands using DNA interaction, antibacterial and in vitro cytotoxicity," Journal of Coordination Chemistry, vol. 72, no. 12, pp. 1937-1956, 2019.

[76] F. Trudu, F. Amato, P. Vaňhara, T. Pivetta, E. M. PeñaMéndez, and J. Havel, "Coordination compounds in cancer: past, present and perspectives," Journal of Applied Biomedicine, vol. 13, no. 2, pp. 79-103, 2015.

[77] Z. Qiu, K. Zou, L. Zhuang et al., "Hepatocellular carcinoma cell lines retain the genomic and transcriptomic landscapes of primary human cancers," Scientific Reports, vol. 6, no. 1, p. 27411, 2016.

[78] M. López-Lázaro, "A simple and reliable approach for assessing anticancer activity in vitro," Current Medicinal Chemistry, vol. 22, no. 11, pp. 1324-1334, 2015.

[79] K. S. Prasad, L. S. Kumar, S. C. Shekar, M. Prasad, and H. D. Revanasiddappa, "Oxovanadium complexes with bidentate $\mathrm{N}, \mathrm{O}$ ligands: synthesis, characterization, DNA binding, nuclease activity and antimicrobial studies," Chemical Sciences Journal, vol. 12, pp. 1-10, 2011.

[80] R. S. Joseyphus and M. S. Nair, "Antibacterial and antifungal studies on some Schiff base complexes of zinc(II)," Mycobiology, vol. 36, no. 2, pp. 93-98, 2008.

[81] A. A. Al-Amiery, A. A. H. Kadhum, and A. B. Mohamad, "Antifungal and Antioxidant Activities of Pyrrolidone Thiosemicarbazone complexes," Bioinorganic Chemistry and Applications, vol. 2012, Article ID 795812, 2012. 